\author{
AUS DEM LEHRSTUHL \\ FÜR ANATOMIE \\ MOLEKULARE UND ZELLULÄRE ANATOMIE \\ PROF. DR. WILL W. MINUTH \\ DER FAKULTÄT FÜR MEDIZIN \\ DER UNIVERSITÄT REGENSBURG
}

\title{
THE INTERFACE BETWEEN GENERATING RENAL TUBULES AND A POLYESTER FLEECE IN COMPARISON TO THE INTERSTITIUM OF THE DEVELOPING KIDNEY
}

DIE BEDEUTUNG VON STRUKTURELLEN ELEMENTEN DES INTERSTITIUMS BEI DER REGENERATION VON RENALEM PARENCHYM

\author{
Inaugural - Dissertation \\ zur Erlangung des Doktorgrades \\ der Zahnmedizin \\ der \\ Fakultät für Medizin \\ der Universität Regensburg
}

vorgelegt von

Christian Miess 



\author{
AUS DEM LEHRSTUHL \\ FÜR ANATOMIE \\ MOLEKULARE UND ZELLULÄRE ANATOMIE \\ PROF. DR. WILL W. MINUTH \\ DER FAKULTÄT FÜR MEDIZIN \\ DER UNIVERSITÄT REGENSBURG
}

\title{
THE INTERFACE BETWEEN GENERATING RENAL TUBULES AND A POLYESTER FLEECE IN COMPARISON TO THE INTERSTITIUM OF THE DEVELOPING KIDNEY
}

DIE BEDEUTUNG VON STRUKTURELLEN ELEMENTEN DES INTERSTITIUMS BEI DER REGENERATION VON RENALEM PARENCHYM

\author{
Inaugural - Dissertation \\ zur Erlangung des Doktorgrades \\ der Zahnmedizin \\ der \\ Fakultät für Medizin \\ der Universität Regensburg
}

vorgelegt von

Christian Miess 
Dekan:

1. Berichterstatter:

2. Berichterstatter:
Prof. Dr. Bernhard Weber

Prof. Dr. Will W. Minuth

Prof. Dr. Dr. Peter Proff

Tag der mündlichen Prüfung: 07.06.2011 
Meinen Eltern und meiner Schwester in großer Dankbarkeit gewidmet. 


\title{
The Interface Between Generating Renal Tubules and a Polyester Fleece in Comparison to the Interstitium of the Developing Kidney
}

\author{
C. Miess, A. Glashauser, L. Denk, U. deVries, and W. W. Minuth \\ Department of Molecular and Cellular Anatomy, University of Regensburg, University Street 31, \\ D-93053 Regensburg, Germany
}

(Received 14 December 2009; accepted 9 March 2010; published online 23 March 2010)

Associate Editor Michael S. Detamore oversaw the review of this article.

\begin{abstract}
An increasing number of investigations is dealing with the repair of acute and chronic renal failure by the application of stem/progenitor cells. However, accurate data concerning the cell biological mechanisms controlling the process of regeneration are scarce. For that reason new implantation techniques, advanced biomaterials and morphogens supporting regeneration of renal parenchyma are under research. Special focus is directed to structural and functional features of the interface between generating tubules and the surrounding interstitial space. The aim of the present experiments was to investigate structural features of the interstitium during generation of tubules. Stem/ progenitor cells were isolated from neonatal rabbit kidney and mounted between layers of a polyester fleece to create an artificial interstitium. Perfusion culture was performed for 13 days in chemically defined Iscove's Modified Dulbecco's Medium containing aldosterone $\left(1 \times 10^{-7} \mathrm{M}\right)$ as tubulogenic factor. Recordings of the artificial interstitium in comparison to the developing kidney were performed by morphometric analysis, scanning and transmission electron microscopy. The degree of differentiation was registered by immunohistochemistry. The data reveal that generated tubules are embedded in a complex network of fibers consisting of newly synthesized extracellular matrix proteins. Morphometric analysis further shows that the majority of tubules within the artificial interstitium develops in a surprisingly close distance between 5 and $25 \mu \mathrm{m}$ to each other. The abundance of synthesized extracellular matrix acts obviously as a spacer keeping generated tubules in distance. For comparison, the same principle of construction is found in the developing parenchyma of the neonatal kidney. Most astonishingly, scanning electron microscopy reveals that the composition of interstitial matrix is not homogeneous but differs along a cortico-medullary axis of proceeding tubule development.
\end{abstract}

Keywords-Tissue engineering, Perfusion culture, Kidney, Tubule, Artificial interstitium, Collagen type III.

Address correspondence to W. W. Minuth, Department of Molecular and Cellular Anatomy, University of Regensburg, University Street 31, D-93053 Regensburg, Germany. Electronic mail: will.minuth@vkl.uni-regensburg.de

\section{INTRODUCTION}

Recovery from renal failure requires the replacement of injured tissue with new cells that restore epithelial integrity and functionality within tubules. An increasing number of papers is therefore dealing with strategies for repair of parenchyma by the help of stem/progenitor cells. ${ }^{5,12}$ However, recent data show that an effective therapy is still far away from a widespread clinic application. Unsolved issues in renal tissue engineering are the concentration of stem/progenitor cells at the site of damage, their integration in a diseased environment, the process of differentiation into nephron-specific cells, and the spatial development of tubules within the kidney. ${ }^{32}$

Part of actual research is focusing on cell biological mechanisms involved in the formation of tubules during regeneration. ${ }^{4}$ Due to the spatial microarchitecture of the kidney experiments are frequently performed applying three-dimensional culture experiments in combination with primary cells or cell lines. ${ }^{2,30}$ Normally the cells are coated by extracellular matrix proteins such as collagen or Matrigel ${ }^{\circledR}$. Applying serum-containing medium the cells migrate within the coat of extracellular matrix proteins, proliferate and aggregate to form cysts and tubules. ${ }^{23}$ However, during long-term culture the coat of extracellular matrix proteins hinders exchange of nutrition and respiratory gas. Up-to-date typical nephron-specific differentiation and the synthesis of an intact basal lamina in generated tubules are lacking. Since the cells do not exhibit an fetal origin, it remains questionable to what extent these models reflect a stem/progenitor cell-derived process of tubule regeneration.

Pioneering experiments related to regeneration with stem/progenitor cells were performed by culturing isolated nephrogenic mesenchyme from mouse fetus on one side and spinal cord on the other side of a filter. 9,24 
In these transfilter experiments both tissues were coated by agarose. During culture in medium containing serum the interaction between both tissues through the pores results in the development of tubules within the mesenchyme. Most impressive of this method is the high degree of cellular differentiation within generated tubules. However, the need of an inducer tissue secreting morphogens, the necessary application of serum containing undefined factors, the limited time for maintenance, and the minimal amount of tissue available for cell biological analysis pertains to the disadvantages.

Development of tubules was further investigated on intact metanephric organ anlage cultured within a filter insert. ${ }^{8}$ To facilitate exchange of respiratory gas the tissue is kept near the gas-fluid interface. The integrity of the growing organ supports at the begin of culture tubule development, but the continuously increasing mass of parenchyma hinders the provision with fresh nutrition, which in turn limits further growth. For that reason a capillary for perfusion of medium is placed inside the hilus. During a 10-day period of culture in medium containing serum the explants process through the early stages of nephrogenesis. Using this type of protocol the onset of necrosis is delayed, while morphology of the growing organ is well preserved.

To avoid coating by extracellular matrix proteins and to raise renal tubules in chemically defined medium, an advanced culture technique was developed. Renal stem/progenitor cells are placed between two layers of a polyester fleece to simulate an artificial interstitium. ${ }^{19}$ The space between the fibers facilitates exchange of nutrition and respiratory gas. Transport of always fresh and chemically defined medium in a perfusion container guarantees a constant provision with nutrition and respiratory gas during long-term culture. Experiments demonstrate that the generation of tubules at the interface of this artificial interstitium is a powerful model to investigate processes involved in renal regeneration. For example, development of renal stem/progenitor cells can be induced by aldosterone. ${ }^{11}$ The signal is mediated via the mineralocorticoid receptor (MR), since antagonists such as spironolactone or canrenoate prevent tubulogenic development. ${ }^{18}$ Disturbing the molecular interaction between MR and heat shock protein 90 by geldanamycin or radicicol results in a lack of tubule formation. ${ }^{17}$

Thus, the interface between two layers of polyester fleece promotes the spatial development of numerous tubules in culture under controlled conditions. Since there are no proteins derived from a coating process, it became possible for the first time to investigate synthesis of interstitial matrix proteins surrounding generated tubules. To obtain first insights in the arrangement of these compounds morphometry, electron microscopy and immunohistochemistry was performed. Most astonishingly, the presented data reveal that generating tubules avoid a direct contact but keep a minimal distance to each other. This spatial separation is caused by linking the basal lamina of tubules with synthesized fibers of the extracellular matrix and with fibers of the polyester fleece. Finally, for comparison the interface between tubules and extracellular matrix was investigated in the developing kidney.

\section{MATERIALS AND METHODS}

\section{Isolation of Tissue Containing Renal Stem/Progenitor Cells}

For the culture experiments 1-day-old New Zealand rabbits were anesthetized with ether and killed by cervical dislocation. Both kidneys were removed and dissected from pole to pole into a ventral and dorsal part as described earlier. ${ }^{11}$ By stripping off the capsula fibrosa with fine forceps a thin tissue layer containing numerous epithelial stem/progenitor cells within collecting duct ampullae and nephrogenic mesenchymal stem/progenitor cells can be harvested (Fig. 1a).

\section{Mounting Stem/Progenitor Cells in a Tissue Carrier for Perfusion Culture}

For generation of tubules isolated renal tissue is placed in plane position between layers of polyester fleece (I-7, Walraf, Grevenbroich, Germany) measuring $5 \mathrm{~mm}$ in diameter during culture. This sandwichlike configuration creates an artificial interstitium with the freshly isolated tissue in the middle and the polyester fleece covering the upper and lower side (Fig. 1b). ${ }^{11,19}$

The sandwich set-up containing renal stem/progenitor cells was mounted then in a base ring of a Minusheet ${ }^{\circledR}$ tissue carrier. First, a polyester fleece measuring $13 \mathrm{~mm}$ in diameter was placed in the tissue carrier. Then, the sandwich set-up was inserted and covered by a further polyester fleece with $13 \mathrm{~mm}$ in diameter. The tissue carrier was used in a perfusion culture container with horizontal flow characteristics (Minucells and Minutissue, Bad Abbach, Germany). After closing the lid of the perfusion culture container, the layers of fleece keep the isolated tissue in central and flat position (Fig. 1c). As shown earlier the interface between the fleece layers produces an artificial interstitium promoting the spatial development of tubules during the culture period over 13 days. The area for tubule formation was $5 \mathrm{~mm}$ in diameter and up to $250 \mu \mathrm{m}$ in height. 
(a)

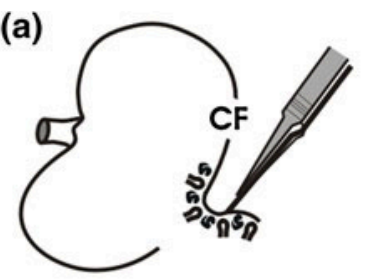

(b)

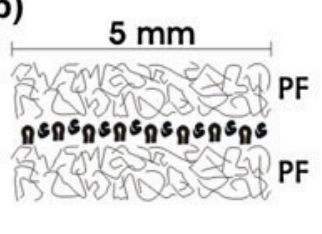

(c)

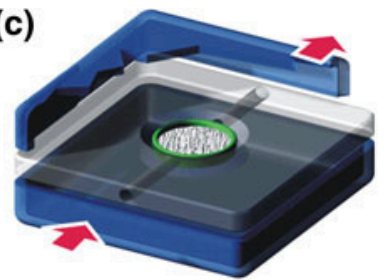

(d)

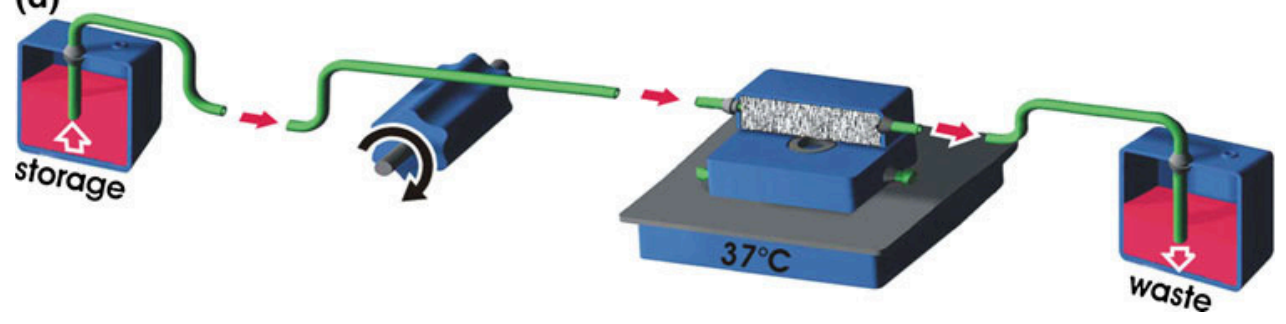

FIGURE 1. Schematic illustration of isolating renal stem/progenitor cells and generation of tubules at the interface of an artificial interstitium (a-d). (a) By stripping off the capsula fibrosa (CF) from neonatal rabbit kidney by forceps renal stem/ progenitor cells within mesenchyme and collecting duct ampullae can be isolated. (b) Isolated tissue is placed between two layers of polyester fleece (PF). (c) For stabilization the tissue is mounted in a tissue carrier and inserted in a culture container with horizontal flow (arrow). (d) During perfusion culture fresh medium is transported (arrow) for 13 days at a rate of $1.25 \mathrm{~mL} / \mathrm{h}$ by a peristaltic pump. To maintain a constant temperature of $37^{\circ} \mathrm{C}$, the culture container is placed on a thermoplate and covered with a lid.

\section{Perfusion Culture}

To generate tubules perfusion culture was performed as described earlier (Fig. 1d). ${ }^{11,18}$ During a period of 13 days always fresh medium was transported with $1.25 \mathrm{~mL} / \mathrm{h}$ by an IPC N8 peristaltic pump (Ismatec, Wertheim, Germany). To maintain a constant temperature of $37{ }^{\circ} \mathrm{C}$ the perfusion culture container was placed on a thermoplate (Medax, Kiel, Germany) and covered with a transparent lid.

For the culture chemically defined IMDM (Iscove's Modified Dulbecco's Medium including Phenolred, GIBCO/Invitrogen, Karlsruhe, Germany) with $50 \mathrm{mmol} / 1 \mathrm{HEPES}$ (GIBCO) for maintenance of a constant $\mathrm{pH}$ of 7.4 under atmospheric air was used. To prevent infections an antibiotic-antimycotic cocktail $(1 \%$, GIBCO) was present in all culture media. As tubulogenic factor aldosterone $\left(1 \times 10^{-7} \mathrm{M}\right.$, Fluka, Taufkirchen, Germany) was added.

\section{Histochemical Labeling}

To analyze cell biological features, cryosections of $20 \mu \mathrm{m}$ thickness were prepared and fixed in ice-cold ethanol. After washing with phosphate buffered saline (PBS) the specimens were blocked with PBS containing $1 \%$ bovine serum albumin (BSA) and 10\% horse serum for $30 \mathrm{~min}$. For soybean agglutinin-labeling (SBA, Vector, Burlingame, USA) the samples were exposed to fluorescein-isothiocyanate (FITC)-conjugated lectin diluted 1:2000 in blocking solution for $45 \mathrm{~min}$ as earlier described. ${ }^{18}$ For immunohistochemical label monoclonal antibodies such as mab anti-laminin $\gamma 1$ (kindly provided by Dr. L. Sorokin, Lund, Sweden), ${ }^{19}$ mab anti-P ${ }_{C D}$ Amp 1, ${ }^{27}$ mab anti-Na/K-ATPase alpha 5 (Developmental Studies Hybridoma Bank, Iowa City, USA) and mab anti-collagen type III (III-53, Calbiochem, Schwalbach, Germany) was applied in blocking solution. After washing with phosphatebuffered saline (PBS) containing $1 \%$ bovine serum albumin (BSA), the specimens were then incubated for $45 \mathrm{~min}$ with donkey-anti-mouse-IgG-fluoresceinisothiocyanate (FITC) or goat-anti-rat-IgG-rhodamine (Jackson Immunoresearch Laboratories, West Grove, USA) diluted 1:50 in this solution. Following several washes with PBS, the sections were embedded with Slow Fade Light Antifade Kit (Molecular Probes, Eugene, USA) and then analyzed using an Axioskop 2 plus microscope (Zeiss, Oberkochen, Germany). Fluorescence images were taken with a digital camera at a standard exposure time of $1.3 \mathrm{~s}$ and thereafter processed with Corel DRAW 11 (Corel Corporation, Ottawa, Canada).

\section{Confocal Fluorescence Microscopy}

To investigate spatial arrangement of extracellular matrix proteins in generated tubules, confocal fluorescence microscopy with a LSM 710 (Zeiss, Oberkochen, Germany) was performed. Specimens 
were fixed in $70 \%$ ethanol and labeled by Soybean agglutinin (SBA), mab anti-collagen type III and antilaminin $\gamma 1$.

\section{Scanning Electron Microscopy}

To analyze the growth pattern of generated tubules within the polyester interstitium, scanning electron microscopy (SEM) was performed. Specimens were fixed in $70 \%$ ethanol, dehydrated in a graded series of ethanols, transferred in acetone, critical point dried with $\mathrm{CO}_{2}$ and sputter-coated with gold (Polaron E 5100, Watford, GB). Then, the samples were examined in a scanning electron microscope DSM 940 A (Zeiss, Oberkochen, Germany) as described earlier. ${ }^{29}$

\section{Transmission Electron Microscopy}

For transmission electron microscopy, specimens were fixed in $2 \%$ glutaraldehyde containing $0.1 \mathrm{M}$ sucrose and $0.1 \mathrm{M}$ cacodylate buffer for $5 \mathrm{~h}$ at room temperature. After several washes with PBS, the tissue was postfixed in $1 \%$ osmium tetroxide in $1 \mathrm{M}$ PBS, rinsed with PBS, and then dehydrated in graded series of ethanols and embedded in Epon polymerized at $60{ }^{\circ} \mathrm{C}$ for $48 \mathrm{~h}$. Ultrathin sections were performed with a diamond knife on an ultramicrotome EM UC6 (Leica GmbH, Wetzlar, Germany). Sections were collected onto grids (200 mesh) and contrasted using 2\% uranyl acetate and lead citrate.

\section{Morphometry}

To determine the amount of developed tubules, whole mount SBA-labeled specimens were used. The distance between the basal lamina of neighboring tubules was measured on magnified DIN A4 illustrations. To register the number of generated tubules, WCIF ImageJ (Bethesda, MD, USA) was used as morphometric program (Fig. 2b). Independently from their length the individual distance between SBA-labeled tubules within a microscopic opening of $500 \times 850 \mu \mathrm{m}$ was registered.

\section{Amount of Cultured Constructs}

A total of 48 specimens was isolated and kept in culture for the present study. All of the experiments were performed at least in triplicates. The data provided in the text are the mean of three independent experiments. All experiments are in accordance with the animal ethics committee, University of Regensburg, Regensburg, Germany.
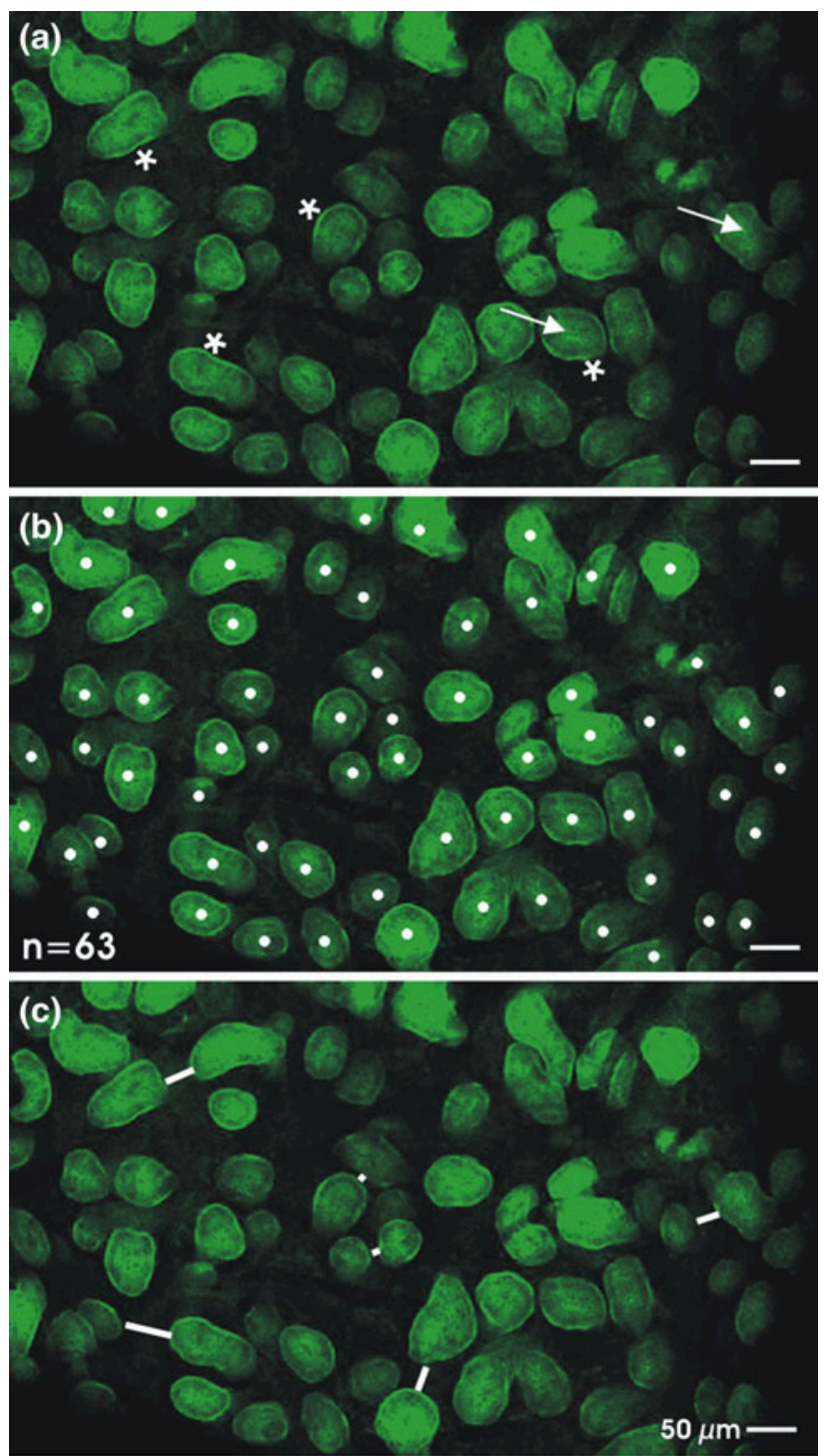

(d) 59

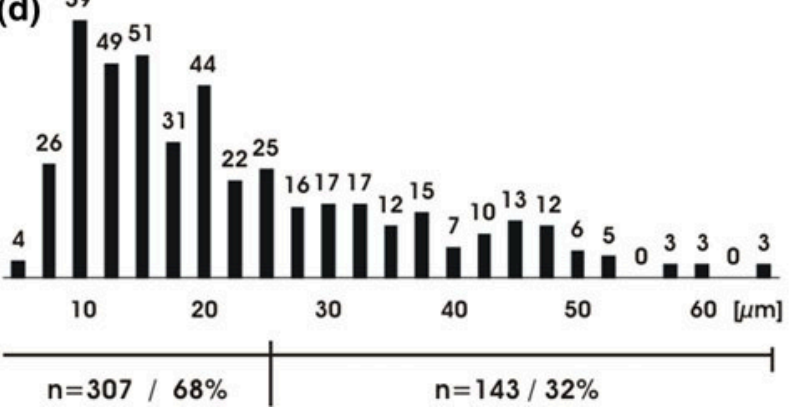

FIGURE 2. Confocal fluorescence microscopy on SBA-labeled tubules generated over 13 days $(a-d)$. (a) Tubules exhibit a basal lamina (asterisk) and a lumen (arrow). (b) Morphometry on a microscopic opening of $500 \times 850 \mu \mathrm{m}$ shows in this individual experiment 63 (white spot) developed tubules. (c) Example demonstrates that generated tubules grow in small-, medium- and big-sized interstitial distances (white lines). (d) Morphometry of 450 recordings shows that $68 \%(n=307)$ of tubules exhibit a distance between 5 and $25 \mu \mathrm{m}$, while $32 \%(n=143)$ are separated by a distance between 26 and $65 \mu \mathrm{m}$. 


\section{RESULTS}

\section{Arrangement of Tubules}

The renal stem/progenitor cells were isolated from the cortex of neonatal rabbit kidney and cultured between layers of polyester fleece. For 13 days the tissue was kept in perfusion culture with chemically defined IMDM containing aldosterone (Fig. 1).

To analyze the spatial development of generated tubules, the artificial interstitium was opened at the end of culture by separating the polyester fleece layers with fine forceps. Specimens were labeled then by SBA to visualize the spatial distribution of generated tubules. Confocal fluorescence microscopy demonstrates that numerous labeled tubules can be seen in a longitudinal, transversal and oblique course (Fig. 2a). All of them exhibit a continuously developed basal lamina, lining epithelial cells and a visible lumen.

To determine the number of SBA-labeled tubules, cross sections were analyzed by morphometry. In the presented case, 63 tubules are detected (Fig. 2b). Surprisingly, whole mount label further demonstrates that generated tubules do not contact each other (Fig. 2c). Small, medium, and wide distances can be registered. To obtain exact information about the gap between generated tubules, 450 recordings were made (Fig. 2d). The data show that a gap smaller than $2.5 \mu \mathrm{m}$ does not occur. A distance between 5 and $25 \mu \mathrm{m}$ was found in 307 cases $(68 \%)$. It is obvious that the most frequently found space is $10 \mu \mathrm{m}(n=59)$. In contrast, gaps between 26 and $65 \mu \mathrm{m}$ are less frequently detected $(n=143)$. The accumulation of gaps in a range between 5 and $25 \mu \mathrm{m}$ is a clear hint that the distance between generated tubules does not occur accidentally but appears to be organized and tightly packed.

\section{Extracellular Matrix Between Generated Tubules}

For more detailed analysis the interstitial space between generated tubules was investigated after immunohistochemical label (Fig. 3). Immuno-positive label for collagen type III is found in both along the basal lamina and in the gap between generated tubules (Fig. 3a). This observation shows that at the basal aspect of generated tubules interstitial matrix is synthesized. The experiments further demonstrate that laminin $\gamma 1$ is localized together with collagen type III in the basal lamina of generated tubules, but also in the space between (Fig. 3b). In consequence, collagen type III and laminin $\gamma 1$ appear as candidates creating the gap between generating tubules (Fig. 3c).

\section{Structural Features of the Interstitial Space Between Generated Tubules}

To obtain detailed insight in the ultrastructure of the interstitial space between generated tubules, transmission electron microscopy was performed (Fig. 4). The surface view shows that generated tubules exhibit a polarized epithelium (Fig. 4a). The luminal plasma membrane of epithelial cells borders a clearly visible lumen. The luminal and lateral plasma membranes are separated by a tight junctional complex. The basal plasma membrane is in contact with a basal lamina. Higher magnification depicts that the basal lamina is composed of several layers as it is known from the kidney (Fig. 4b). A lamina rara interna faces the basal plasma membrane of epithelial cells, while a lamina densa and a lamina rara externa cover the tubules at the outer surface. The lamina fibroreticularis acts as connecting element to the interstitial space containing numerous collagen fibers. In some cases,
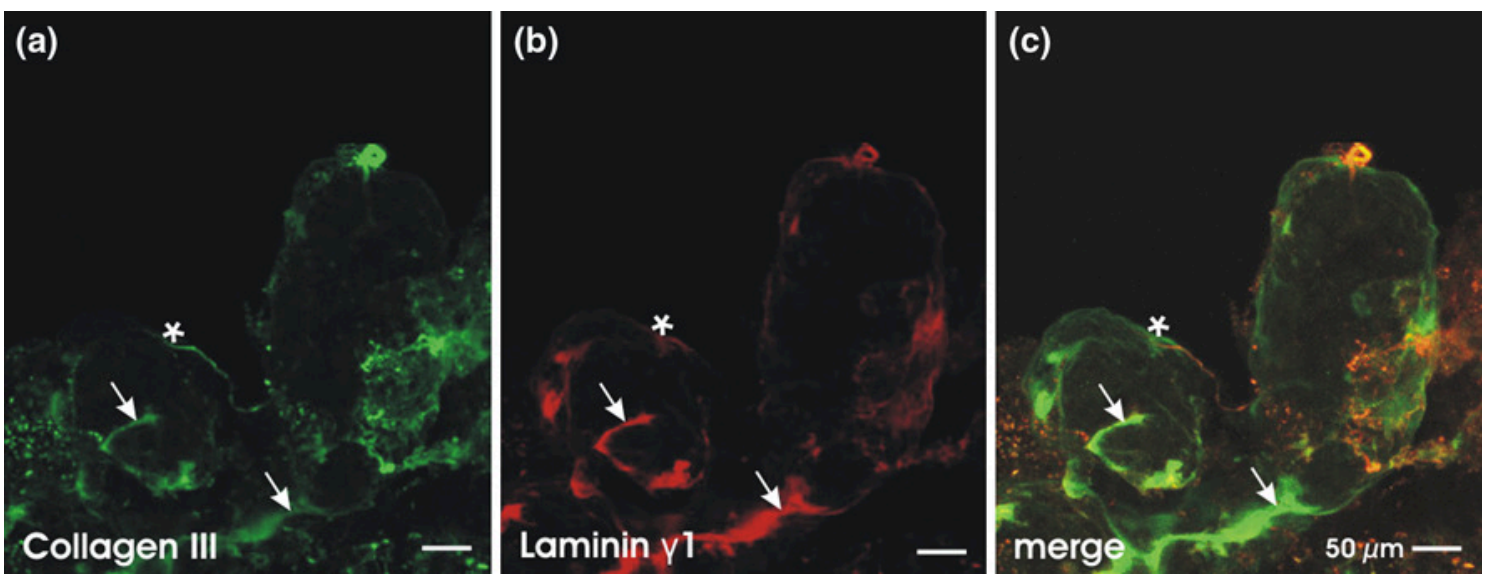

FIGURE 3. Confocal analysis of whole mount-labeled tubules generated over 13 day at the interface of an artificial interstitium (a-c). (a) Label for collagen type III is found at the basal lamina (asterisk) and within the gap (arrow) between the tubules. (b) Label for laminin $\gamma 1$ is found within the basal lamina (asterisk) and within the gap (arrow) between the tubules. (c) Merge illuminates co-localization of both molecules within the basal lamina (asterisk) and within the intertubular gap (arrow). 

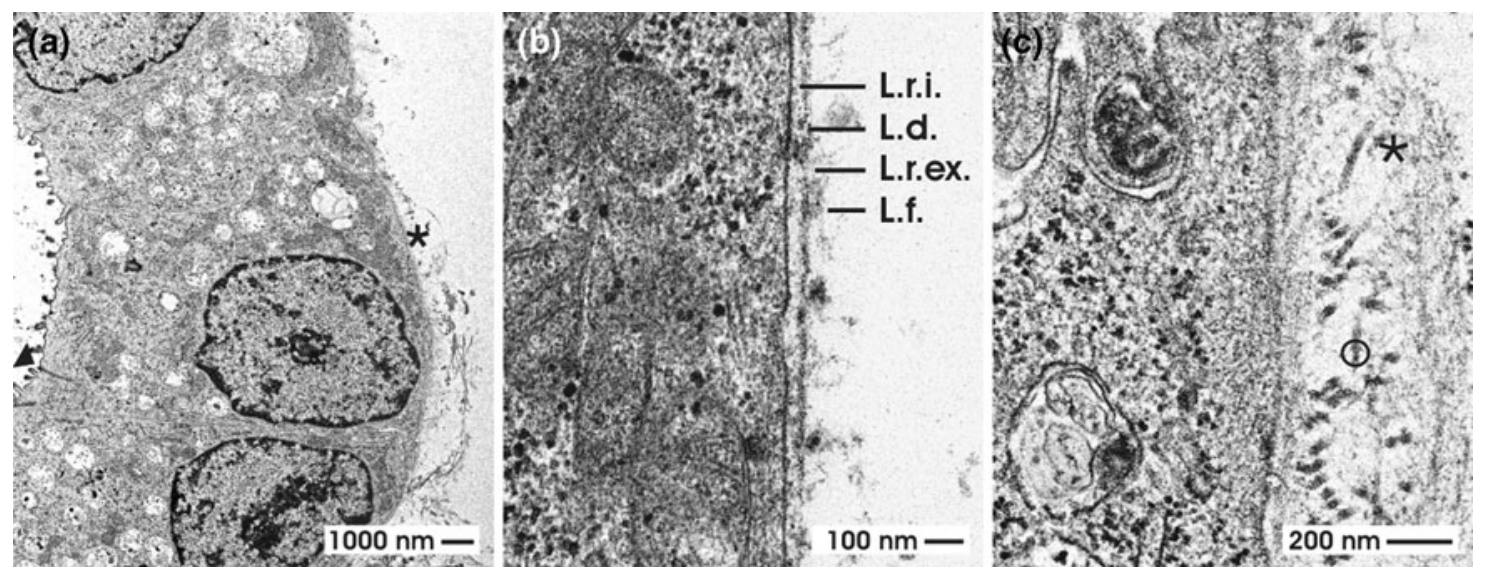

FIGURE 4. Transmission electron microscopy on generated tubules after 13 days of culture (a-c). (a) Surface view demonstrates that tubules contain a polarized epithelium. At the border between the luminal and lateral plasma membrane a tight junctional complex is developed (arrow head). The basal side of the epithelium rests on a basal lamina (asterisk). (b) Higher magnification shows the basal aspect of the epithelium and the basal lamina consisting of a lamina rara interna (I.r.i.), lamina densa (I.d.), lamina rara externa (l.r.ex.) and a lamina fibroreticularis (l.f.). (c) Higher magnification depicts that the lamina fibroreticularis (asterisk) reveals occasionally an increased thickness containing numerous collagenous fibrils $(0)$.

the lamina rara externa and the lamina fibroreticularis show an increased thickness (Fig. 4c). The inconstant thickness of these layers may explain the varying distances between generated tubules as shown in Fig. 2.

SEM was accomplished to receive three-dimensional information about molecules spacing generated tubules (Figs. 5a, 5d, and 5g). A surface view demonstrates tubules contacting the polyester fleece. The polyester fibers exhibit an average diameter of $10 \mu \mathrm{m}$ and a smooth surface without recognizable roughness. Development of tubules occurs in the vicinity of fibers (Fig. 5a). Micrographs further show that a basal lamina is covering the complete outer surface of tubules. A part of tubules grows in a parallel fashion (Fig. 5d), while others exhibit a dichotomous branching (Fig. 5g). Numerous of the tubules have no contact, while others have only a loose contact to the fibers of the polyester fleece. Higher magnification illustrates that the basal lamina of generated tubules is covered by a network of extracellular matrix proteins obviously synthesized by interstitial cells (Figs. 5b, 5e, and 5h). Collagen fibers are lining as well between the basal lamina of tubules as to neighboring fibers of the polyester fleece.

On the basal lamina of generated tubules dispersed interstitial cells are found (Fig. 5b, 5e, and 5h). They exhibit a more or less round shape. In some cases their surface appears smooth (Fig. 5b), while in other cases a network of filopodia or extracellular matrix fibers is protruding from the interstitial cells (Figs. 5e and 5h).

However, looking by SEM to filopodia of interstitial cells it cannot be decided, where a cell is ending and at which point the extracellular matrix starts (Figs. 5b, $5 \mathrm{e}$, and $5 \mathrm{~h}$ ). For that reason TEM was carried out to analyze the transition from cellular protrusions to the extracellular matrix (Figs. 5c, 5f, and 5i). Ultrathin sections reveal that always a close contact exists between protrusions of interstitial cells and attached fibers consisting of synthesized extracellular matrix. Surprisingly, at the contact site the plasma membrane appears solubilized and the microstructure is barely recognizable. Instead, amorphous material is protruding through the plasma membrane into the cytoplasm.

\section{Interstitium of the Developing Renal Parenchyma}

Features of the interstitium found in generated tubules may be influenced by the culture environment (Figs. 3-5). For comparison the interstitium of developing parenchyma in neonatal kidney was investigated (Figs. 6-9). Semithin sections through the outer cortex of neonatal rabbit kidney show in vertical (Figs. 6a and 6b) and longitudinal (Fig. 6c) direction tubules embedded in the interstitium. It can be recognized at this early stage of development that tubules do not exhibit a close contact to each other but are separated by an astonishingly wide interstitial space.

To obtain further detailed data concerning the interstitium of developing parenchyma in neonatal kidney, histochemical and ultrastructural analysis were performed. In the developing cortex four different zones can be distinguished (Fig. 7a). Underneath the organ capsule both the population of mesenchymal (mes) nephrogenic stem/progenitor cells and within the tip of the collecting duct ampulla (A) epithelial stem/ progenitor cells are localized. At the neck of the 

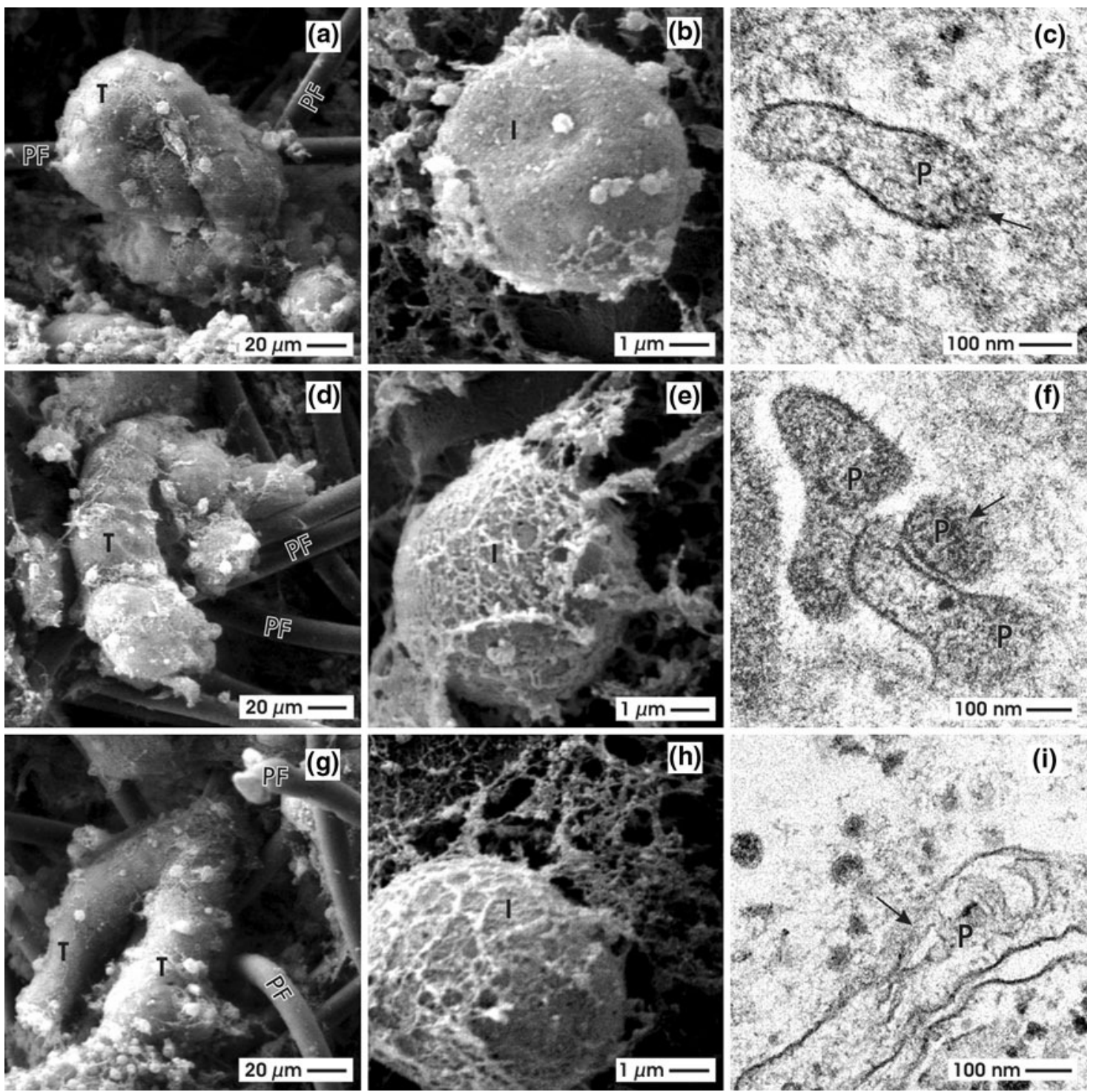

FIGURE 5. Scanning (a, b, d, e, g, h) and transmission (c, $f, i)$ electron microscopy of tubules generated for 13 days at the interface of an artificial polyester interstitium. $(a, d, g)$ SEM shows that fibers of the polyester fleece (PF) are detected in a longitudinal, transversal and oblique course. They exhibit a homogeneous composition and a smooth surface without recognizable protrusions or roughness. The diameter of fibers is $10 \mu \mathrm{m}$ in average. Development of tubules (T) occurs in the space between the fibers. (a) A basal lamina is covering completely the outer surface of tubules. (d, g) A part of tubules grows in a parallel fashion, while others exhibit a dichotomous branching. (b) On the outer surface of generated tubules dispersed interstitial cells (I) are found exhibiting a round shape. (e, h) On the surface of interstitial cells a network of filopodia and extracellular matrix is recognized. $(c, f, i)$ TEM demonstrates that a close contact exists between protrusions (P) of interstitial cells and attached fibers consisting of synthesized extracellular matrix. At the contact site (arrow) the plasma membrane appears solubilized. Amorphous material is protruding through the plasma membrane into the cytoplasm.

collecting duct ampulla comma-shaped bodies as first visible signs of nephron formation are detected. Down in the neighborhood of the ampulla shaft further matured nephrons are present. Thus, the axis of a developmental gradient is lining vertically from the organ capsule through the cortex corticis, the tip, the neck and finally to the shaft of the collecting duct ampulla. Along this gradient the specific features of the interstitium were investigated.
A clearly orientated semithin section shows that the mesenchymal nephrogenic stem/progenitor cells beyond the organ capsule and the epithelial stem/ progenitor cells in the tip of the collecting duct ampulla are separated by a wide interstitium (arrows) (Fig. 7b). A wide interstitial cleft is also recognizable at the lateral side of the tip, the neck down to the shaft of the collecting duct ampulla. Here, matured Principal (P) and Intercalated (IC) cells become visible. 

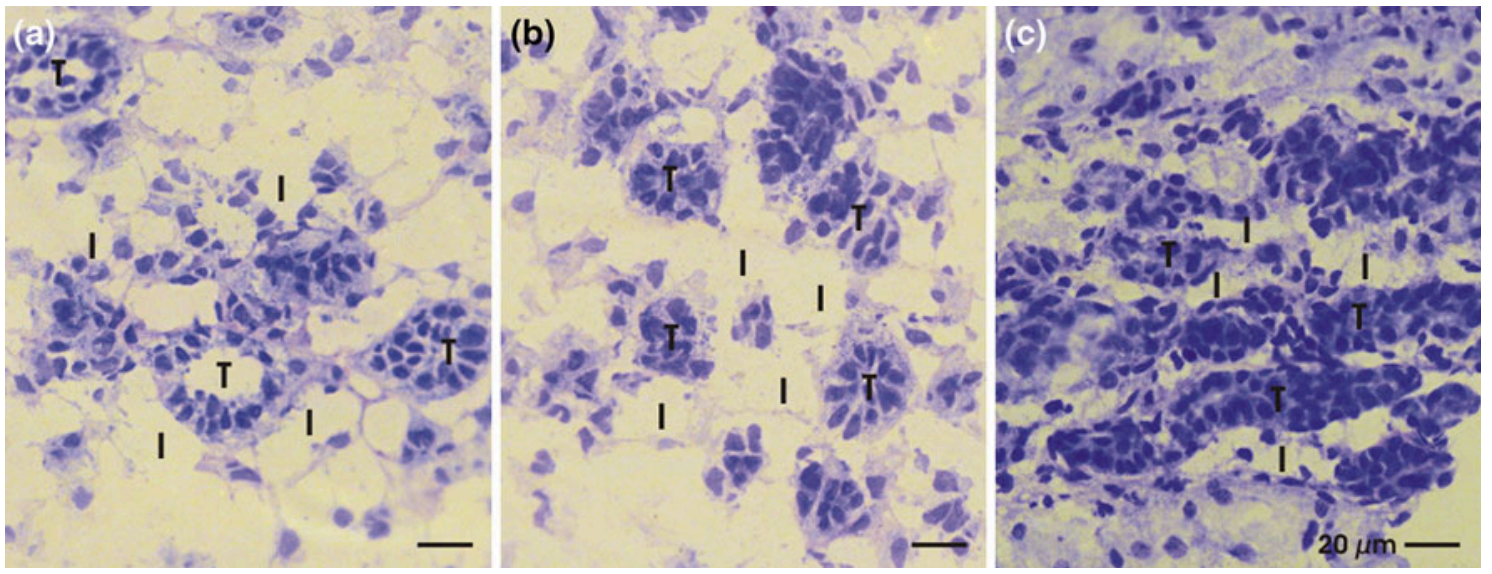

FIGURE 6. Light microscopy of renal parenchyma within the developing zone of neonatal rabbit kidney (a-c). (a, b) Cross and (c) in longitudinal sections depict tubules $(\mathrm{T})$ within the interstitium (I).
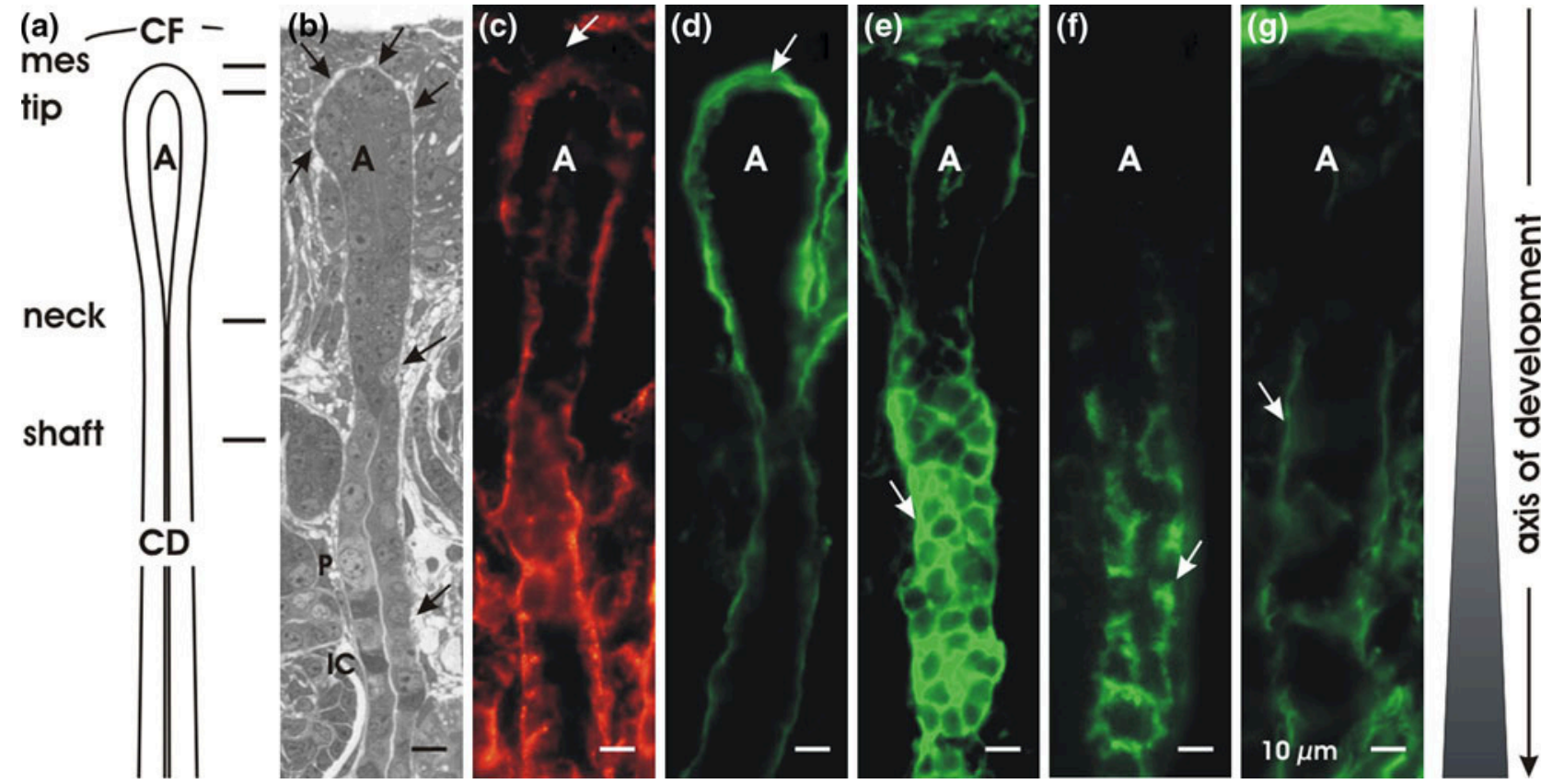

FIGURE 7. Features of the interstitium in the developing renal parenchyma. (a) Beyond the capsula fibrosa (CF) the mesenchyme (mes), the tip, neck and shaft of the collecting duct (CD) ampulla (A) of neonatal kidney are seen. (b) Semithin section shows that the mesenchyme and the tip of the collecting duct ampulla are separated by a distinct interstitial space (arrows) lining down to the lateral side of the tip, neck and shaft of the collecting duct ampulla. Matured Principal ( $P$, light) and Intercalated (IC, dark) cells become visible in the shaft of the collecting duct ampulla. (c) Immuno-label for laminin $\gamma 1$ is lacking in the mesenchyme beneath the capsule (arrow), while distinct label is found in the basal lamina of all zones of the collecting duct ampulla. (d) Intensive label for $\mathrm{P}_{\mathrm{CD}}$ Amp1 is found at the basal lamina of the ampulla tip (arrow), while the reaction is continuously decreasing towards the neck and shaft. (e) An inverse reaction is found for SBA label. Only faint reaction is detected in the basal lamina of the tip, while within the neck and shaft of the collecting duct ampulla strong cellular label is present (arrow). (f) Label for Na/K ATPase alpha 5 is lacking within the tip of the collecting duct ampulla, while intensive reaction is found in the neck and shaft (arrow). (g) Collagen type III is lacking in the mesenchyme and around the tip of the collecting duct ampulla, while primary arise is found around the neck (arrow).

To obtain more information about the developmental processes, histochemistry was performed (Figs. $7 \mathrm{c}-7 \mathrm{~g}$ ). Label for laminin $\gamma 1$ is lacking in the mesenchyme underneath the organ capsule (arrow), but it is found in the basal lamina of all zones of the collecting duct ampulla (Fig. 7c). Intensive reaction for $\mathrm{P}_{\mathrm{CD}} \mathrm{Amp1}$ is found at the basal lamina of the ampulla tip (arrow), but the label is decreasing towards the neck and shaft of the ampulla (Fig. 7d). An inverse result is found for SBA label (Fig. 7e). Faint reaction is detected in the basal lamina of the tip, while within the neck and shaft of the collecting duct 

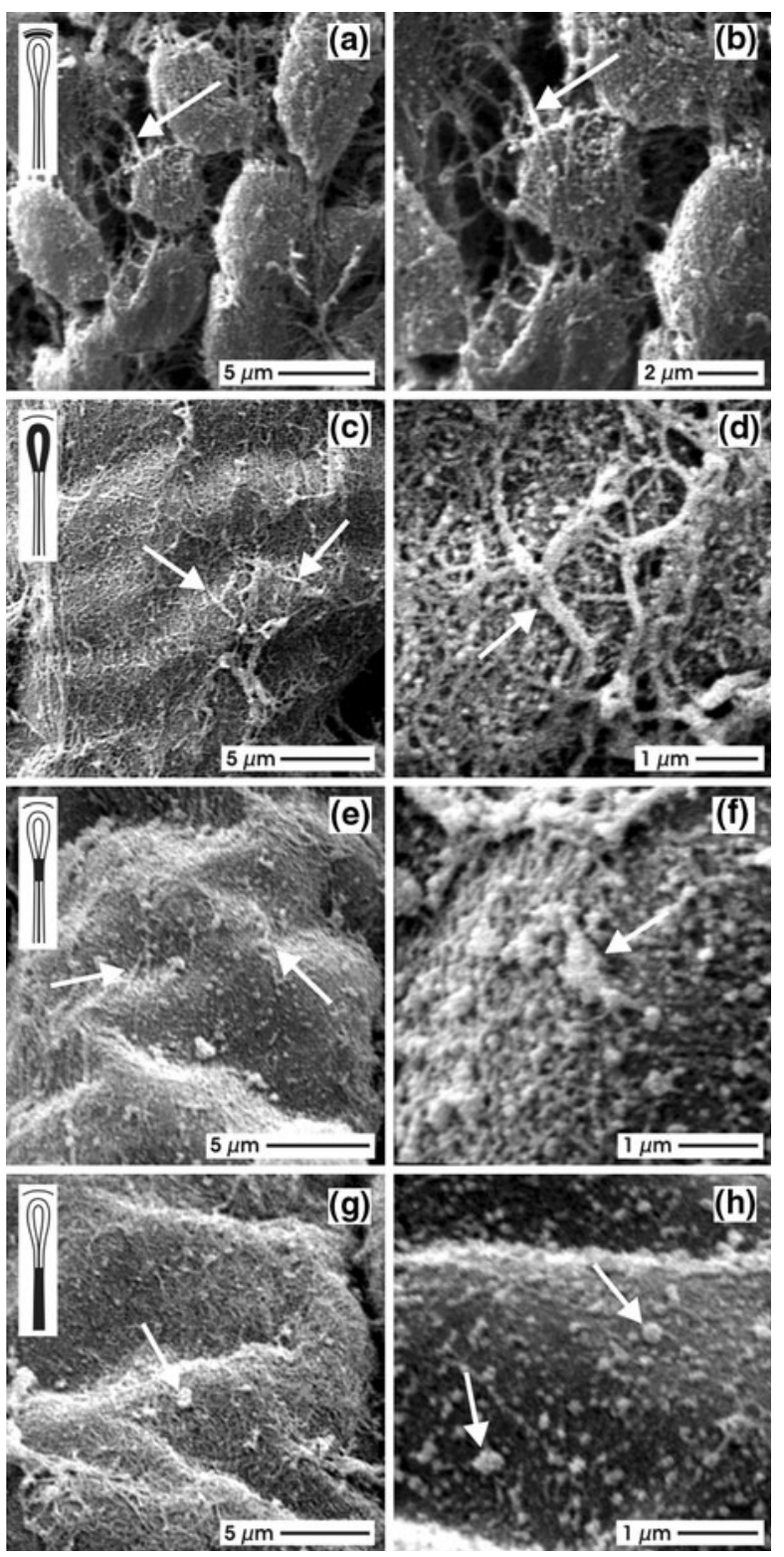

FIGURE 8. Scanning electron microscopy (SEM) in the cortex of neonatal rabbit kidney demonstrates structural elements of the interstitium in the mesenchyme $(a, b)$ beyond the capsule, (c, d) around the tip, $(e, f)$ the neck and $(g, h)$ the shaft of the collecting duct ampulla. $(a, b)$ The surface of mesenchymal cells exhibits short microvilli and numerous protrusions (arrow) searching contact to neighboring cells. It cannot be recognized if the protrusions consist exclusively of cellular material or if also extracellular matrix is included. (c, d) View to the tip of the collecting duct ampulla reveals a rough surface including arborising fibers (arrow) consisting of extracellular matrix. (e, f) Around the neck of the collecting duct ampulla the number and size of fibers decreases (arrow), so that the surface becomes smooth. Here numerous round particles adherent to fibers can be recognized. $(g, h)$ Along the shaft of the collecting duct ampulla the number of round particles (arrows) within the lamina fibroreticularis decreases and strong fibers are lacking.
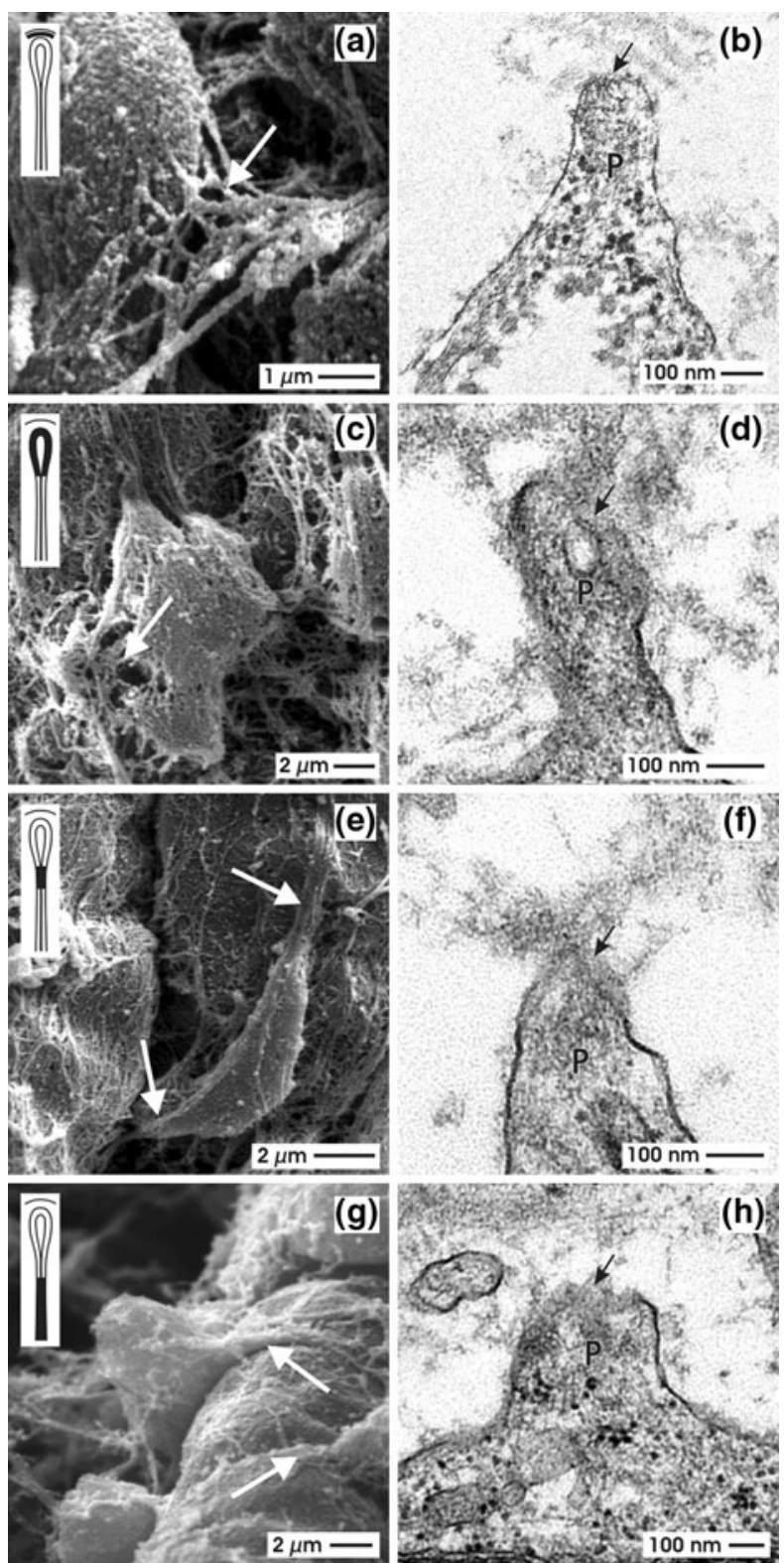

FIGURE 9. Scanning (SEM) (a, c, e, g) and transmission (TEM) $(b, d, f, h)$ electron microscopy of the cortex in neonatal rabbit kidney. (a) SEM depicts that cells in the mesenchyme are connected over a loose network of thin fibers (arrow). (c) Around the tip of the collecting duct ampulla flat interstitial cells with numerous filopodia and a dense network of extracellular matrix fibers are seen (arrow). (e) At the neck of the ampulla interstitial cells are flat showing two or three foot-like protrusions (arrows). At the contact site with the extracellular matrix numerous filopodia are present. (g) Along the shaft of the ampulla interstitial cells exhibit a cuboidal shape. At the cell side facing the extracellular matrix remarkable food-like protrusions and filopodia keeping contact with extracellular matrix (arrows). (b, d, f, h) TEM illuminates that a close contact exists between protrusions $(P)$ of interstitial cells and attached fibers consisting of extracellular matrix. At the contact site the plasma membrane appears solubilized. The amorphous material protrudes through the plasma membrane into the cytoplasm (arrow). 
ampulla strong cellular label is present. Within the collecting duct ampulla label for $\mathrm{Na} / \mathrm{K}$ ATPase alpha 5 is lacking (Fig. 7f). In contrast, intensive reaction for $\mathrm{Na} / \mathrm{K}$ ATPase alpha 5 is found in the ampulla shaft (arrow) and the further matured collecting duct. Surprisingly, collagen type III is lacking in the mesenchyme and around the tip of the collecting duct ampulla, while primary appearance of label is found around the neck (arrow) and the shaft of the ampulla (Fig. 7g). Thus, collagen type III is not synthesized as a primary structural element in the developing renal interstitium.

\section{Structural Elements Within the Interstitium}

To gain insights in structural features of the developing interstitium, scanning electron microscopy (SEM) was performed (Fig. 8). SEM demonstrates underneath the organ capsule mesenchymal nephrogenic stem/progenitor cells. It is obvious that they are keeping an astonishingly wide distance to each other (Fig. 8a). The surface of mesenchymal cells exhibits short microvilli and numerous protrusions searching contact to neighboring cells (Fig. 8b). It cannot be recognized if the protrusions consist exclusively of cellular material or if also extracellular matrix is included. In contrast, view to the tip of the collecting duct ampulla reveals a rough surface including numerous arborising fibers (Figs. 8c and 8d). In the neck of the collecting duct ampulla, the number and size of fibers decrease, so that the surface becomes smooth (Figs. 8e and 8f). Yet, numerous more or less round particles adherent to fibers can be recognized (Fig. 8f). In the shaft of the collecting duct ampulla, the number of round particles within the lamina fibroreticularis decreases and strong fibers are lacking (Figs. 8g and 8h). Thus, following the cortico-medullary axis structural elements within the developing interstitium are heterogeneously composed. This kind of segmentation appears in parallel to histochemical changes occurring along the axis between the mesenchymal stem/progenitor cells, the ampulla tip, ampulla neck and ampulla shaft of the collecting duct (Fig. 7).

\section{Cells in the Different Zones of the Developing Interstitium}

To obtain information about cells communicating with structural elements in the developing interstitium, SEM was performed. Thus, the cortex corticis (Fig. 9a), the ampulla tip (Fig. 9c), the ampulla neck (Fig. 9e) and the shaft of the collecting duct ampulla (Fig. 9g) were analyzed. The zone of nephrogenic mesenchyme beyond the organ capsule reveals that numerous cells are embedded in a loose network consisting of thin fibers (arrow) (Fig. 9a). It cannot be decided if cellular protrusions or extracellular matrix or both are seen. Further down, around the tip of the collecting duct ampulla flat interstitial cells with numerous protrusions are localized (Fig. 9c). They are embedded within a dense network of extracellular matrix fibers. At the neck of the ampulla interstitial cells are flat showing two or three foot-like protrusions (arrow) (Fig. 9e). The surface of the cells is smooth. At the contact site with extracellular matrix numerous cellular protrusions are present. In contrast, in the shaft of the ampulla, interstitial cells exhibit a more or less cuboidal shape (Fig. 9g). At the cell side facing the extracellular matrix, remarkable food-like protrusions (arrow) are detected.

SEM illuminates three-dimensional features of cell and extracellular matrix within the developing interstitium (Figs. 9a, 9c, 9e, and 9g). However, following the protrusion of cells it is impossible to recognize a clear demarcation line between the end of the cell and the beginning of extracellular matrix. To investigate this special interface, transmission electron microscopy (TEM) was performed first in the mesenchymal stem/ progenitor cell group within the cortex corticis (Fig. 9b), around the ampulla tip (Fig. 9d), the ampulla neck (Fig. 9f) and the collecting duct ampulla shaft (Fig. 9h). Surprisingly, in all series it was found that both protrusions and extracellular matrix have a close contact to each other. However, this interface is special, since the plasma membrane appears to be solubilized to a more or less degree as it was earlier observed in generated tubules (Figs. 5c, 5f, and 5i). Most interestingly, in all cases the amorphous material of extracellular matrix is protruding through the plasma membrane into the cytoplasm (arrow in Figs. 9b, 9d, 9f, and 9h).

\section{DISCUSSION}

The interstitium is an important functional space occurring in all parenchymal organs. In the kidney it can be recognized as a narrow slit between the basal lamina of tubules and the capillaries. Although barely visible in light microscopy (arrow, Fig. 7b), the interstitial space is of great importance in the healthy kidney. ${ }^{14}$ The interstitium consists of extracellular matrix, the surrounding fluid and the interstitial cells. The skeletonal portion contains mainly collagen type III sustaining the three-dimensional structure of the organ. ${ }^{7}$ All processes of tubule reabsorption and secretion have a transit across the fluid portion localized between the collagen fibers. In the diseased kidney, inflammatory cells infiltrate the interstitium. The resulting increase of interstitial cells and extracel- 
lular matrix causes renal fibrosis. ${ }^{6}$ During this process tubule cells loose epithelial features and convert to fibroblast-like cells. ${ }^{3}$ This epithelial-mesenchymal transition (EMT) is paralleled for example by the expression of fibroblast-specific protein-1(FSP1), ${ }^{13}$ heat shock protein 47 (HSP 47) $)^{10,16,21}$ and $\alpha$-smooth muscle actin (SMA). ${ }^{31}$

In contrast, mesenchymal-epithelial transition (MET) plays an important role, when stem/progenitor cells are applied to support regeneration in acute or chronic renal failure., ${ }^{1,33}$ The key for a successful therapeutic concept is to learn about involved cell biological processes promoting epithelial differentiation during tubule formation. The process of regeneration includes mechanisms organizing the spatial distribution of tubules. In the kidney, this separation is caused by extracellular matrix proteins synthesized during organ development. To obtain insights in the arise of extracellular matrix elements developing renal parenchyma in the kidney and tubules generating at the interface of an artificial polyester interstitium was analyzed.

\section{Interstitium of the Developing Renal Parenchyma}

Insights in the structure of the interstitium can be obtained on an exactly orientated section through the cortex of neonatal rabbit kidney (Figs. $7 \mathrm{a}$ and $7 \mathrm{~b}$ ). Developing, maturing, and matured tissue can be found here lining along a developmental axis from the organ capsule through the cortex down to the medulla. ${ }^{15}$ In the cortex, four different zones of maturation can be distinguished. It comprises the mesenchyme (including nephrogenic stem/progenitor cells), the tip (including epithelial stem/progenitor cells), the neck (maturing), and the shaft (matured) of the collecting duct ampulla (Fig. 7a).

Light microscopy further reveals that the interstitium of developing renal parenchyma is extending as well between the mesenchymal cells as around the basal aspect of the collecting duct ampulla (arrow, Fig. 7b). The interstitial space can be further recognized as a slit running from the tip to the neck and down to the shaft of the collecting duct ampulla. Here, the arise of matured $\mathrm{P}$ and IC cells within the collecting duct tubule can be seen.

SEM illuminates better that the mesenchyme containing nephrogenic stem/progenitor cells exhibits astonishingly wide intercellular spaces reflecting an extended interstitium (Figs. 8a and 8b). In addition, numerous anastomizing fibers connect the sides of neighboring cells. Performing SEM it cannot be decided yet if the contacting structures consist exclusively of cellular protrusions or if also extracellular matrix is involved (Fig. 9a). However, TEM clearly elucidates that this interface is special. It consists of both synthesized extracellular matrix fibers in close contact with finger-like cellular protrusions (Figs. 9b, 9d, 9f, and $9 \mathrm{~h}$ ). Most conspicuous is that amorphous extracellular matrix material is protruding through the plasma membrane into the cytoplasm.

\section{Heterogeneity of Structural Elements in the Developing Interstitium}

The tip of the collecting duct ampulla is the specific site, where mesenchymal nephrogenic stem/progenitor cells interact reciprocally with epithelial stem/progenitor cells during nephrogenesis. ${ }^{20,25}$ This molecular process results in the formation of a comma-shaped body as a first morphological sign of a developing nephron. Thus, the interstitium at the ampulla tip was analyzed by SEM (Figs. 8c and 8d). A dense network of extracellular matrix is found here. It consists of numerous fibers with varying diameter as it was shown earlier. ${ }^{26,29}$ In contrast, in the ampulla neck the roughness, the diameter and the length of the skeletonal elements decrease (Figs. 8e and 8f). Instead, more or less round and bone-shaped particles are found to be attached to the fibers of the extracellular matrix. At the shaft of the collecting duct ampulla, the surface of extracellular matrix becomes smooth and fibers become rare (Figs. $8 \mathrm{~g}$ and $8 \mathrm{~h}$ ). In consequence, the portions of the interstitium along the four zones of the collecting duct ampulla are heterogeneously composed. Up to date it is speculative if the different shape is due to different protein composition. The heterogeneity of the extracellular matrix could coincidence with particular functions occurring during nephrogenesis. However, more information about individual structural composition is up to date not available and has to be investigated in future.

\section{Arise of Structural Elements in the Interstitium}

The main structural element within the renal interstitium is collagen type III or earlier described as reticulin. $^{7,22}$ One could assume that the primary expression of collagen type III is a driving force forming the structural portion of the interstitium and featuring thereby the distance between generating tubules. To obtain exact information, the primary appearance of collagen type III was investigated (Fig. 7g). Most interestingly, immuno-label demonstrates that collagen type III is lacking as well in the nephrogenic mesenchyme as along the tip and neck of the collecting duct ampulla. However, further down in the shaft of the collecting duct ampulla primary appearance of collagen type III is found. In contrast, label for laminin $\gamma 1$ is present not only in the shaft, but 
also in the neck and tip of the collecting duct ampulla, while in the mesenchyme it could not be detected (Fig. 7c). ${ }^{19}$ Thus, label for collagen type III is missing in the zone of renal stem/progenitor cells, but it is co-localized with laminin $\gamma 1$ in the maturing zone along the shaft of the collecting duct ampulla. In consequence, the experiments clearly show that collagen type III is not the primary skeletonal element of the interstitium in developing renal parenchyma. More appropriate candidates are earlier described structural elements such as collagen type IV, ${ }^{29}$ SBA-labeled molecules within the basal lamina (Fig. 7e), microfibers ${ }^{26}$ or $\mathrm{P}_{\mathrm{CD}} \mathrm{Amp1}^{28}$ (Fig. 7d).

\section{Interface Between Generating Tubules}

Experiments were further made to investigate the structured portion of the interstitium keeping generating tubules in distance (Figs. 2a- 2c). The surface view on whole mount SBA-labeled specimens demonstrates that generated tubules do not fuse, but are separated by each other. Morphometric analysis elucidates that a majority of the tubules generated at an artificial interstitium exhibits a distance in the range between 5 and $25 \mu \mathrm{m}$ (Fig. 2d). Up to date a reason for the discrete distance between generated tubules is not known. Moreover, generated tubules exhibit a co-localization of collagen type III and laminin $\gamma 1$ along the basal lamina (Fig. 3), as it is found in the developing part of the kidney (Figs. $7 \mathrm{c}$ and $7 \mathrm{~g}$ ). The reaction of collagen type III is also found in the interstitium of generated tubules. This result illuminates that collagen type III appears as an important molecule linking the artificial polyester interstitium with the basal lamina of generated tubules. SEM and TEM support this finding, since the basal lamina of generated tubules is surrounded by bundles of synthesized extracellular matrix (Figs. 4 and 5a, 5d, 5g). Regarding morphometric data (Fig. 2d), it appears that the linking of polyester fibers and synthesized extracellular matrix is determining the distance between generated tubules. Experiments are under work to illuminate further the interface influencing the development at an artificial interstitium.

\section{REFERENCES}

\footnotetext{
${ }^{1}$ Anglani, F., et al. The renal stem cell system in kidney repair and regeneration. Front. Biosci. 13:6395-6405, 2008.

${ }^{2}$ Ash, S. R., F. E. Cuppage, M. E. Hoses, and E. E. Selkurt. Culture of isolated renal tubules: a method of assessing viability of normal and damaged cells. Kidney Int. 1:55-60, 1975.
}

${ }^{3}$ Burns, W. C., P. Kantharidis, and M. C. Thomas. The role of tubular epithelial-mesenchymal transition in progressive kidney disease. Cells Tissues Organs 1-3:222-231, 2007.

${ }^{4}$ Bussolati, B., and G. Camussi. Stem cells and repair of kidney damage. G Ital Nefrol. 2:161-168, 2008.

${ }^{5}$ Chhabra, P., and K. L. Brayman. The use of stem cells in kidney disease. Curr. Opin. Org. Transplant. 1:72-78, 2009.

${ }^{6}$ Eddy, A. A. Progression in chronic kidney disease. $A d v$. Chronic Kidney Dis. 4:353-365, 2005.

${ }^{7}$ Fleischmajer, R., et al. Immunochemical analysis of human kidney reticulin. Am. J. Pathol. 5:1225-1235, 1992.

${ }^{8}$ Giuliani, S., et al. Ex vivo whole embryonic kidney culture: a novel method for research in development, regeneration and transplantation. J. Urol. 1:365-370, 2008.

${ }^{9}$ Grobstein, C. Trans-filter induction of tubules in mouse metanephrogenic mesenchyme. Exp. Cell Res. 2:424-440, 1956.

${ }^{10}$ Hamilton, A. M., and J. J. Heikkila. Examination of the stress-induced expression of the collagen binding heat shock protein, hsp47, in Xenopus laevis cultured cells and embryos. Comp. Biochem. Physiol. A Mol. Integr. Physiol. 1:133-141, 2006.

${ }^{11}$ Heber, S., L. Denk, K. Hu, and W. W. Minuth. Modulating the development of renal tubules growing in serumfree culture medium at an artificial interstitium. Tissue Eng. 2:281-292, 2007.

${ }^{12}$ Hopkins, C., J. Li, F. Rae, and M. H. Little. Stem cell options for kidney disease. J. Pathol. 2:265-281, 2009.

${ }^{13}$ Iwano, M., et al. Evidence that fibroblasts derive from epithelium during tissue fibrosis. J. Clin. Invest. 3:341-350, 2002.

${ }^{14}$ Kaissling, B., and M. Le Hir. The renal cortical interstitium: morphological and functional aspects. Histochem. Cell Biol. 2:247-262, 2008.

${ }^{15}$ Kloth, S., et al. Transitional stages in the development of the rabbit renal collecting duct. Differentiation 1:21-32, 1998.

${ }^{16}$ Manwell, L. A., and J. J. Heikkila. Examination of KNK437- and quercetin-mediated inhibition of heat shockinduced heat shock protein gene expression in Xenopus laevis cultured cells. Comp. Biochem. Physiol. A Mol. Integr. Physiol. 3:521-530, 2007.

${ }^{17}$ Minuth, W. W., A. Blattmann, L. Denk, and H. Castrop. Mineralocorticoid receptor, heat shock proteins and immunophilins participate in the transmission of the tubulogenic signal of aldosterone. J. Epithel. Biol. Pharmacol. 11:24-34, 2008.

${ }^{18}$ Minuth, W. W., L. Denk, K. Hu, H. Castrop, and C. Gomez-Sanchez. The tubulogenic effect of aldosterone is attributed to intact binding and intracellular response of the mineralocorticoid receptor. Cent. Eur. J. Biol. CEJB 2(3):3307-3325, 2007.

${ }^{19}$ Minuth, W. W., L. Sorokin, and K. Schumacher. Generation of renal tubules at the interface of an artificial interstitium. Cell. Physiol. Biochem 4-6:387-394, 2004.

${ }^{20}$ Nigam, S. K., and M. M. Shah. How does the ureteric bud branch? J. Am. Soc. Nephrol. 20:1465-1469, 2009.

${ }^{21}$ Razzaque, M. S., V. T. Le, and T. Taguchi. Heat shock protein 47 and renal fibrogenesis. Contrib. Nephrol. 148: 57-69, 2005.

${ }^{22}$ Razzaque, M. S., et al. Synthesis of type III collagen and type IV collagen by tubular epithelial cells in diabetic nephropathy. Pathol. Res. Pract. 11:1099-1104, 1995.

${ }^{23}$ Sariola, H. Nephron induction. Nephrol. Dial. Transplant. 17(9):88-90, 2002. 
${ }^{24}$ Saxén, L., and E. Lehtonen. Embryonic kidney in organ culture. Differentiation 1:2-11, 1987.

${ }^{25}$ Schmidt-Ott, K. M., et al. Novel regulators of kidney development from the tips of the ureteric bud. J. Am. Soc. Nephrol. 7:1993-2002, 2005.

${ }^{26}$ Schumacher, K., R. Strehl, and W. W. Minuth. Characterization of micro-fibers at the interface between the renal collecting duct ampulla and the cap condensate. Nephron. Exp. Nephrol. 2:e43-e54, 2003.

${ }^{27}$ Strehl, R., S. Kloth, J. Aigner, P. Steiner, and W. W. Minuth. PCDAmp1, a new antigen at the interface of the embryonic collecting duct epithelium and the nephrogenic mesenchyme. Kidney Int. 6:1469-1477, 1997.

${ }^{28}$ Strehl, R., and W. W. Minuth. Partial identification of the mab (CD)Amp1 antigen at the epithelial-mesenchymal interface in the developing kidney. Histochem. Cell Biol. 5:389-396, 2001.

${ }^{29}$ Strehl, R., V. Trautner, S. Kloth, and W. W. Minuth. Existence of a dense reticular meshwork surrounding the nephron inducer in neonatal rabbit kidney. Cell Tissue Res. 3:539-548, 1999.

${ }^{30}$ Sutterlin, G. G., and G. Laverty. Characterization of a primary cell culture model of the avian renal proximal tubule. Am. J. Physiol. 1 Pt 2:R220-R226, 1998.

${ }^{31} \mathrm{Xu}, \mathrm{G}$., and X. Liu. Aldosterone induces collagen synthesis via activation of extracellular signal-regulated kinase 1 and 2 in renal proximal tubules. Nephrology (Carlton) 8:694$701,2008$.

${ }^{32}$ Yokoo, T., A. Fukui, K. Matsumoto, and M. Okabe. Stem cells and kidney organogenesis. Front. Biosci. 13:2814 2832, 2008.

${ }^{33}$ Zeisberg, E. M., S. E. Potenta, H. Sugimoto, M. Zeisberg, and R. Kalluri. Fibroblasts in kidney fibrosis emerge via endothelial-to-mesenchymal transition. J. Am. Soc. Nephrol. 12:2282-2287, 2008. 



\section{Abstract}

Immer mehr Untersuchungen beschäftigen sich mit der Therapie von akuten und chronischen Nierenerkrankungen. Ein innovativer Therapieansatz untersucht die Verwendung von Stamm/Progenitorzellen. Allerdings gibt es bisher nur wenige Informationen bezüglich der zellbiologischen Mechanismen, die eine Regeneration unterstützen. Im Focus der Grundlagenforschung stehen neue Implantationstechniken, innovative Biomaterialien zum Anheften von Stamm/Progenitorzellen und morphogene Substanzen, die eine Regeneration stimulieren. Ein spezielles Augenmerk wird dabei auf die strukturellen und funktionellen Wechselbeziehungen zwischen regenerierenden Tubuli und dem erkrankten Interstitium gelegt.

Um einen Einblick in die Entstehung von Tubuli zu erhalten, wurden Stamm/Progenitorzellen der neonatalen Kaninchennieren isoliert und zwischen 2 Lagen aus Polyestervlies kultiviert. Mit diesem neuen Verfahren wird ein künstliches Interstitium erzeugt, in dem mit Hilfe der Perfusionskultur und einem chemisch Iscove's Modified Dulbecco's Medium über 13 Tage strukturierte Tubuli entstehen. Die morphometrischen Analysen, sowie die Befunde aus Raster- und Transmissionselektronenmikroskopie geben erste Einblicke in die räumliche Orientierung von wachsenden Tubuli in diesem künstlichen Interstitium. Die aktuellen Daten zeigen, dass sich dabei die Tubuli in der Mehrzahl in einem Abstand von 5 bis $25 \mu \mathrm{m}$ anordnen.

Weitere Untersuchungen zeigen, dass sich das gleiche Konstruktionsprinzip im embryonalen Parenchym der neonatalen Nieren wiederfindet. Aufnahmen mit dem Rasterelektronenmikroskop belegen, dass die Zusammensetzung der extrazellulären Matrix im Interstitium nicht homogen ist, sondern sich entlang einer cortico-medullären Achse der entstehenden Tubuli verändert. 


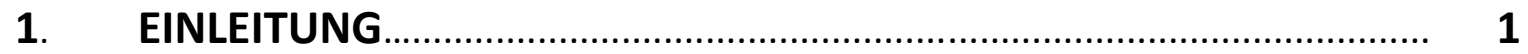

2. MATERIAL UND METHODEN................................................................... 5

2.1. Isolierung von Stamm/Progenitorzellen aus der neonatalen Kaninchenniere.

2.2. Anheftung der Stamm/Progenitorzellen auf einem

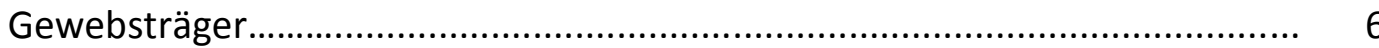

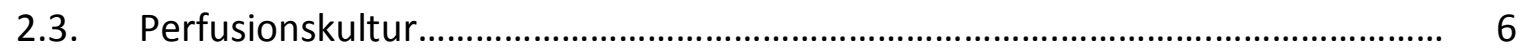

2.4. Histochemische Markierung ......................................................................... 7

2.5. Konfokale Fluoreszenzmikrokopie................................................................. 8

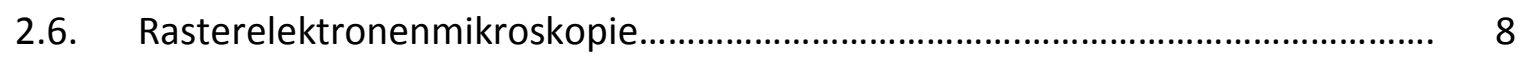

2.7. Transmissionselektronenmikroskopie............................................................. 8

2.8. Morphometrie........................................................................................ 9

2.9. Anzahl der kultivierten Konstrukte.................................................................. 9

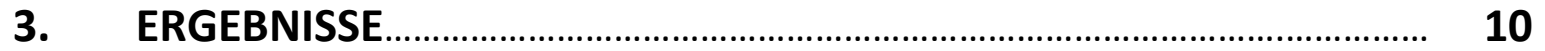

3.1. Die strukturelle Anordnung von generierten Tubuli.......................................... 10

3.2. Extrazelluläre Matrix zwischen generierten Tubuli.............................................. 12

3.3. Strukturelle Eigenschaften des interstitiellen Raumes

zwischen generierten Tubuli......................................................................... 13

3.4. Interstitium des embryonalen renalen Parenchyms.......................................... 16

3.5. Morphologisch erkennbare Strukturelemente

innerhalb des Interstitiums.............................................................................. 19

3.6. Zellen im embryonalen Interstitium.................................................................. 22 


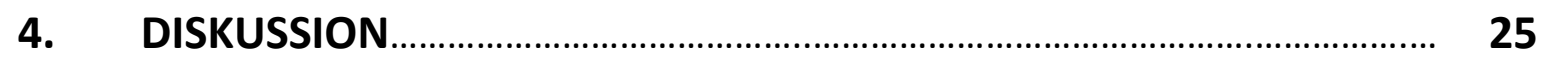

4.1. Das Interstitium des sich entwickelnden renalen Parenchyms.......................... 26

4.2. Heterogenität der Strukturelemente in dem

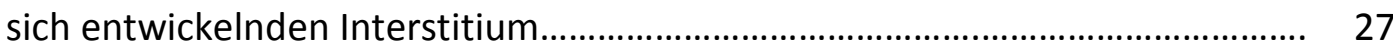

4.3. Entstehung von strukturellen Elementen im

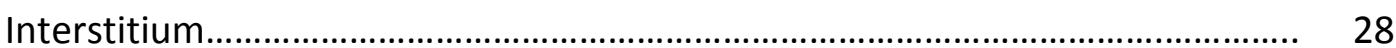

4.4. Grenzfläche zwischen generierten Tubuli......................................................... 29

5. LITERATURVERZEICHNIS ................................................................... 30 


\section{EINLEITUNG}

Ein neuer Therapieansatz beim chronischen und akuten Nierenversagen setzt sich mit dem Ersatz von geschädigtem Parenchym durch neue Zellen auseinander, um damit die Funktionalität innerhalb der Tubuli wiederherzustellen. Ein Blick in eine Datenbank zeigt, dass es immer mehr aktuelle Publikationen von Arbeitsgruppen gibt, die eine Reparatur des Parenchyms mit Hilfe von Stamm/Progenitorzellen beinhalten (Chhabra 2009, Hopkins 2009). Die aktuelle Literatur zeigt jedoch, dass eine effektive und sichere Therapie noch immer weit von einer breiten Klinikanwendung entfernt ist. Gegenstand der aktuellen Untersuchungen ist vor allem die reproduzierbare Implantation von Stamm/Progenitorzellen an den erkrankten Stellen im Organ, die Integration nach einer Implantation und die Entwicklungsprozesse zu nephron-spezifischen Zellen sowie die räumliche Entwicklung der Tubuli innerhalb der Niere (Yokoo 2008).

Ein Teil der aktuellen Forschung konzentriert sich auf zellbiologische Mechanismen, die bei der Bildung von Tubuli während der Regenerierung eine Rolle spielen (Bussolati 2008). Wegen der komplizierten Mikroarchitektur der Niere werden häufig dreidimensionale Kulturexperimente in Kombination mit primären Zellen oder Zelllinien durchgeführt (Ash 1975, Sutterlin 1998). Im Normalfall sind die Zellen dabei mit extrazellulären Matrixproteinen, wie Kollagen oder Matrigel ${ }^{\circledR}$ ummantelt. Bei der Verwendung von serumhaltigem Medium, wandern die Zellen in den Mantel aus extrazellulären Matrixproteinen, proliferieren und vermehren sich, um Zysten und Tubuli zu bilden (Sariola 2002). Jedoch behindert während einer Langzeitkultivierung dieser Mantel aus extrazellulären Matrixproteinen den Austausch von Nahrung und Atemgas. Zudem ist nur eine bedingte nephron-spezifische Differenzierung und keine Synthese von intakter Basallamina festzustellen. Außerdem ist es zu bedenken, dass die dabei verwendeten Zellen keinen embryonalen Ursprung haben. Somit ist fraglich, in wie fern 
diese Versuchsstrategie überhaupt einen von Stamm/Progenitorzellen abgeleiteten Prozess der Tubulusregenerierung widerspiegelt.

Die allerersten bahnbrechenden Experimente zur Therapie mit Hilfe von Stamm/Progenitorzellen wurden von Grobstein (Grobstein 1956) und Saxèn (Saxèn 1987) durchgeführt. Dabei wurde renales metanephrogenes Mesenchym von Mausföten auf der Oberfläche eines Filters angeheftet. Auf der anderen Seite des Filters befand sich embryonales Rückenmark. Bei diesen Transfilterexperimenten waren beide Gewebe mit Agarose umhüllt. Während der Kultivation in serumhaltigem Medium entstanden durch die gegenseitige Beeinflussung der beiden Gewebe Tubuli innerhalb des Mesenchyms. Sehr beeindruckend bei dieser Vorgehensweise ist der hohe Differenzierungsgrad des entstandenen Gewebes. Nachteilig ist jedoch die notwendige Applikation von Serum mit undefinierter Zusammensetzung, sowie die zeitlich begrenzte Kulturdauer der Tubuli und die geringe Ausbeute an Gewebe, das zu zellbiologischer Analyse zur Verfügung steht.

In neuen Experimenten wurde die Entwicklung von Tubuli mit Hilfe von Nierenanlangen innerhalb eines Filtereinsatzes untersucht (Giuliani 2008). Um den Austausch von Atemgas und Nährstoffen zu erleichtern, wird das Gewebe nahe einer Gas-Flüssig-Grenzfläche gehalten. Die Unversehrtheit des wachsenden Organs unterstützt zunächst die Tubulusentwicklung, wobei aber ab einem bestimmten Zeitpunkt das zunehmende Wachstum des Parenchyms die Versorgung mit frischer Nahrung behindert, sodass eine weitere Entwicklung der Tubuli beschränkt wird. Aus diesem Grund wird ein Kapillarsystem zur Perfusion von Medium innerhalb des Hilus eingeführt. Während einer 10-tägigen Kultivationsperiode in serumhaltigem Medium durchlaufen die Explantate die frühen Phasen der Nierenentwicklung. Bei diesem Versuchsaufbau wird die Nekrose verzögert und die entstehende Morphologie des wachsenden Organs gut unterstützt. 
Um eine Ummantelung mit extrazellulären Matrixproteinen oder Agarose während der Kultur von renalen Tubuli zu vermeiden, wurde eine neue Kulturtechnik entwickelt. Renale Stamm/Progenitorzellen werden dabei zwischen zwei Schichten aus Polyestervlies gelegt. Auf diese Weise wird um die Zellen herum ein künstliches Interstitium simuliert (Minuth 2007). Der Platz zwischen den Fasern erleichtert den Austausch von Nährstoffen und Atemgas. Der Transport von immer frischem und vor allem chemisch definiertem Kulturmedium in einem Perfusionsbehälter garantiert auch während einer längerfristigen Kulturperiode eine immer konstante Versorgung. Die durchgeführten Experimente zeigen, dass die Entwicklung von Tubuli an der Grenzfläche des künstlichen Interstitiums ein gelungener Versuchsaufbau ist, um die Prozesse der renalen Regeneration zu untersuchen. So konnte zum Beispiel gezeigt werden, dass die Entwicklung von renalen Stammzellen durch Aldosteron stimuliert wird (Heber 2007). Das Signal wird über den mineralkortikoid Rezeptor (MR) vermittelt, wobei Antagonisten wie Spironolacton oder Canrenoate die Entstehung von Tubuli verhindern (Minuth 2007). Stört man die molekulare Wechselwirkung zwischen dem mineralkortikoid Rezeptor und dem heat-shock Proteinen 70 und 90, unterbleibt die Bildung von Tubuli (Minuth 2007).

In zahlreichen Untersuchungen konnte somit gezeigt werden, dass ein artifizielles Interstitium die räumliche Entwicklung zahlreicher Tubuli unterstützt. Da bei dieser Vorgehensweise keine Ummantelung mit extrazellulären Matrixproteinen oder Agarose stattfindet, ist es möglich geworden, die Synthese von interstitiellen Strukturen zu untersuchen. Um erste Einblicke in die Wechselwirkung zwischen wachsenden Tubuli und dem Interstitium zu erlangen, wurden in der vorliegenden Arbeit morphometrische Analysen, Elektronenmikroskopie und immunhistochemische Markierungen durchgeführt. Dabei zeigt sich, dass generierte Tubuli einen direkten Kontakt zueinander vermeiden, aber einen minimalen Abstand zueinander aufbauen. Die räumliche Aufteilung wird durch die Verbindung zwischen der Basallamina der Tubuli und den synthetischen Fasern des artifiziellen Interstitiums be- 
wirkt. Um einen Bezug zur Organsituation zu erhalten, wurden parallel Untersuchungen an embryonalen Strukturen der Niere durchgeführt. 


\section{MATERIAL UND METHODEN}

\subsection{Isolierung von Stamm/Progenitorzellen aus der neonatalen Kaninchenniere}

Für die Kulturexperimente wurden 1-tag alte Neuseeland-Kaninchen mit Ether anästhesiert und durch einen gezielten Schnitt getötet. Beide Nieren wurden unter sterilen Bedingungen entnommen (Heber 2007) und von Pol zu Pol in einen ventralen und dorsalen Teil zerlegt. Durch Abziehen der Capsula fibrosa mit Hilfe einer feinen Pinzette, enthält man eine dünne Gewebsschicht mit vielen epithelialen Stamm/Progenitorzellen innerhalb der Sammelrohrampullen und peripher verteilten nephrogenen mesenchymalen Stamm/Progenitorzellen (Fig.1a).
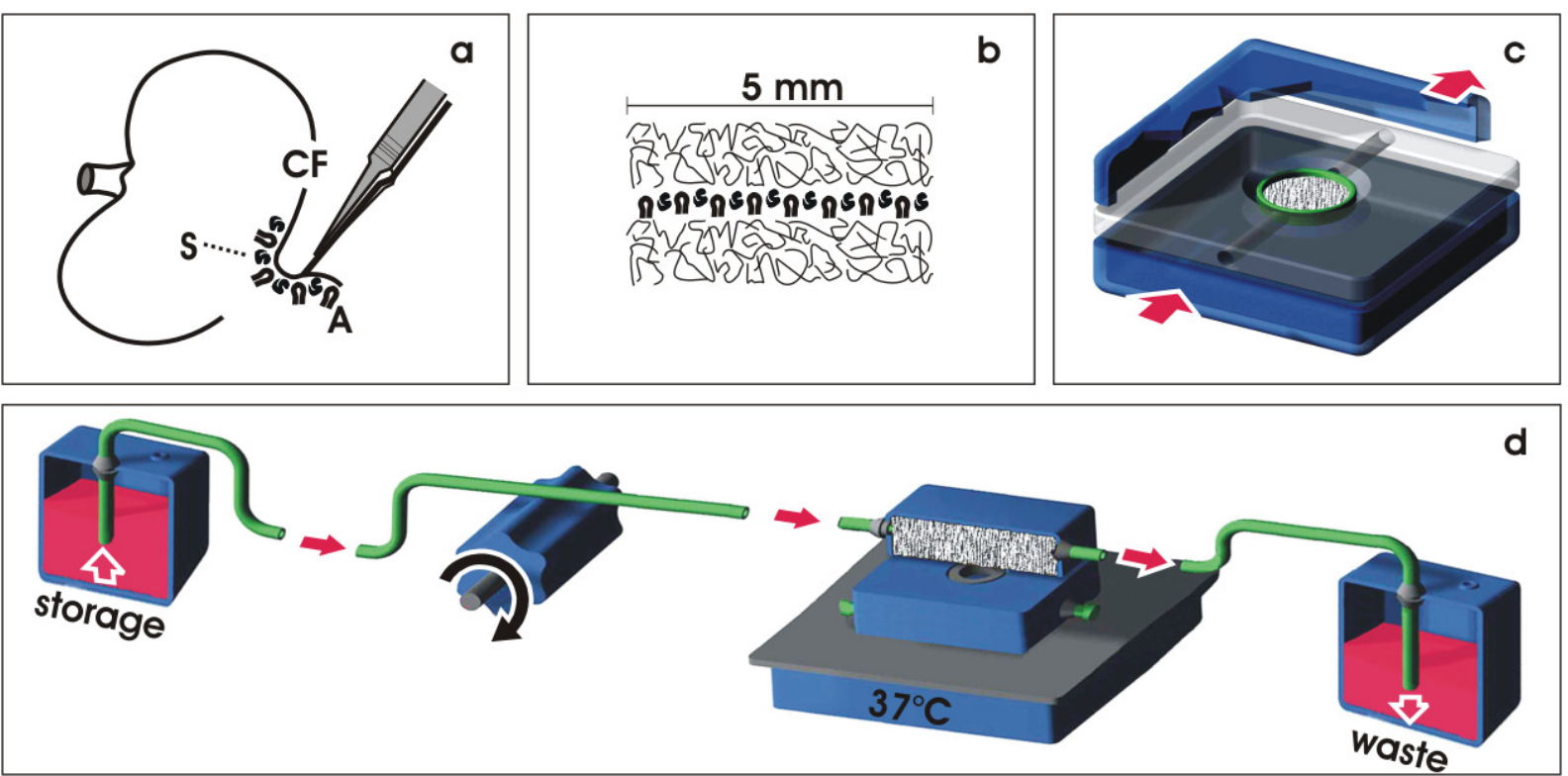

Fig.1a-d.Schematische Darstellung der Isolierung von renalen Stamm/Progenitorzellen und Erzeugung von Tubuli an der Grenzfläche eines künstlichen Interstitiums. (a) Renale Stamm/Progenitorzellen werden durch Abziehen der Capsula fibrosa von neonatalen Kaninchennieren isoliert. (b) Isoliertes embryonales Gewebe wird zwischen zwei Schichten eines Polyestervlieses I-7 platziert. (c) Um eine mechanische Stabilisierung des embryonalen Gewebes zu gewährleisten, wird es innerhalb eines Gewebsträger in den Perfusionskulturkontainer eingelegt. (d) Während der Kultur wird immer frisches Medium über einen Zeitraum von 13 Tagen mit einer Durchflussrate von 1,25 ml/h mit Hilfe einer Peristaltikpumpe transportiert. 


\subsection{Anheften der Stamm/Progenitorzellen auf einem Gewebsträger}

Um Tubuli zu generieren, wird während der Kultur das isolierte Gewebe in waagerechter Position zwischen den Polyestervliesen (I-7, Walraf, Grevenbroich, Deutschland) mit einem Durchmesser von $5 \mathrm{~mm}$ befestigt. Der sandwichähnliche Versuchsaufbau erzeugt ein künstliches Interstitium, bei dem das isolierte Gewebe in der Mitte gehalten wird und auf der oberen und unteren Seite von Vlies umschlossen ist (Fig. 1b)(Minuth 2004, Heber 2007).

Das resultierende Sandwich wird anschließend in einen Minusheet ${ }^{\circledR}$ gespannt. Dabei wird zuerst ein Polyestervlies mit einem Durchmesser von $13 \mathrm{~mm}$ in dem Gewebsträger eingelegt. Dann wird das Sandwich mit dem darin enthaltenen embryonalen Gewebe aufgesetzt und mit einem weiteren Polyestervlies mit einem Durchmesser von $13 \mathrm{~mm}$ bedeckt. Der Gewebsträger wird anschließend in einem Perfusionskulturbehälter mit horizontalen Flussrichtung (Minucells und Minutissue, Bad Abbach, Deutschland) platziert. Nach dem Schließen des Perfusionskulturbehälters werden die Vliesschichten und das isolierte Gewebe in einer zentralen und flachen Position fixiert (Fig. 1c). Der Raum für tubuläre Bildung beträgt im Durchmesser $5 \mathrm{~mm}$ und $250 \mu \mathrm{m}$ in der Höhe.

\subsection{Perfusionskultur}

Zur Herstellung von Tubuli wird eine Perfusionskultur, wie beschrieben, durchgeführt (Herber 2007, Minuth 2007). Während einer Zeitspanne von 13 Tagen wurde immer frisches Medium mit einer Geschwindigkeit von $1.25 \mathrm{ml} / \mathrm{h}$ durch einen IPC N8 Peristaltikpumpe (Ismatec, Wertheim, Deutschland) transportiert. Um eine konstante Temperatur von $37^{\circ} \mathrm{C}$ aufrechtzuerhalten, wurde der Perfusionskulturbehälter auf eine Thermoplatte (Medax, Kiel, Deutschland) gelegt und mit einem durchsichtigen Deckel bedeckt. 
Für die Kultur wurde chemisch definiertes IMDM (Iscove's Modified Dulbecco's Medium mit Phenolrot, GIBCO/Invitrogen, Karlsruhe, Deutschland) mit 50 mmol/I HEPES (GIBCO) für die Aufrechterhaltung eines pH von 7.4 unter atmosphärischer Luft verwendet. Um Infektionen zu verhindern, wurde ein antibiotisch-antimycotischer Cocktail (1\%, GIBCO) in allen Kulturmedien verwendet. Als fördernder Faktor für die Tubulogenese wurde Aldosteron ( 1 × $10^{-7} \mathrm{M}$, Fluka, Taufkirchen, Deutschland) hinzugefügt.

\subsection{Histochemische Markierung}

Um zellbiologische Eigenschaften zu untersuchen, wurden Gefrierschnitte mit einer Dicke von $20 \mu \mathrm{m}$ angefertigt und mit Ethanol fixiert. Nach Inkubation mit phosphatgepufferter Salzlösung (PBS) wurden die Proben für 30 Minuten mit PBS blockiert, welche 1\% Rinderserumalbumin (BSA) und 10\% Pferdeserum enthält. Um die Entstehung von Tubuli zu verfolgen wurden die Proben für die soybeanagglutinin-Markierung (SBA, Vektor, Burlingame, USA) mit Fluorescein-isothiocyanaten (FITC) inkubiert. Dabei war das Lectin 1:2000 verdünnt (Minuth 2007). Für immunhistochemische Markierungen wurden monoklonale Antikörper wie mab anti-Laminin $\gamma 1$ (freundlicherweise zur Verfügung gestellt von Dr. L. Sorokin, Lund, Schweden), mab anti-P $\mathrm{CD}_{\text {Amp }} 1$ (Strehl 1997), mab anti-Na/K-ATPase (Entwicklungsstudien Hybridoma Bank, lowa Stadt, USA) und mab anti-collagen Typ III (III-53, Calbiochem, Schwalbach, Deutschland) inkubiert. Nach einer Inkubation mit der phosphatgepufferten Salzlösung (PBS), wurden die Proben dann für 45 Minuten mit donkey-anti-mouse-IgG-fluoresceinisothiocyanate (FITC) oder goat-anti-rat-IgG-rhodamine (Laboratorien von Jackson Immunoresearch, West Grove, USA) verdünnt und in der Waschlösung inkubiert. Nach mehreren aufeinanderfolgenden Waschschritten mit PBS wurden dann die Schnitte in Slow Fade Light Antifade Kit (Molekulare Untersuchungen, Eugene, USA) eingebettet und mit einem Axioskop 2 und einem Mikroskop (Zeiss, Oberkochen, Deutschland) untersucht. Fluoreszierende Präparate wurden mit einer Digitalkamera und 
einer Standardbelichtungszeit von 1.3 Sekunden aufgenommen und danach mit Corel-DRAW 11 (Corel Vereinigung, Otawa, Kanada) bearbeitet.

\subsection{Konfokale Fluoreszenzmikroskopie}

Um die räumliche Ausrichtung von extrazellulären Matrixproteinen in generierten Tubuli zu untersuchen, wurde konfokale Fluoreszenzmikroskopie mit einem LSM 710 (Zeiss, Oberkochen, Deutschland) durchgeführt. Die Proben wurden dafür in 70\% Alkohol fixiert und mit SBA, mab anti-collagen Typ III und anti-Laminin $\gamma 1$ markiert.

\subsection{Rasterelektronenmikroskopie}

Um das Wachstumsmuster der generierten Tubuli innerhalb des Polyesterinterstitiums zu analysieren, wurde Rasterelektronenmikroskopie (SEM) durchgeführt. Die Proben wurden dazu in 70\% Alkohol fixiert, in einer ansteigenden Reihe von Ethanol dehydriert, in Azeton überführt, um ihnen dann in einer critical-point-Trocknung das restliche Wasser zu entziehen und sie mit Gold zu bespattern (Polaron E 5100, Watford, GB). Danach wurden die Proben in einem Rasterelektronenmikroskop DSM 940 (Zeiss, Oberkochen, Deutschland) untersucht (Strehl 1999).

\subsection{Transmissionselektronenmikroskopie}

Für die Transmissionselektronenmikroskopie wurden die Proben fixiert (2\% Glutaraldehyd, 0,1M Saccharose und 0,1M Cacodylate Puffer). Nach mehreren Waschschritten mit PBS wurde das Gewebe mit 1\%-Osmium Tetroxide in $1 \mathrm{M}$ PBS postfixiert, dann mit PBS gewaschen und danach in ansteigenden Ethanolreihen dehydriert, um es in Epon einzubetten. Die Polymerisation erfolgte bei $60^{\circ} \mathrm{C}$ für 48 
Stunden. Ultradünne Schnitte wurden mit einem Diamantmesser auf einem UltraMicrotom EM UC6 (Leica GmbH, Wetzlar, Deutschland) angefertigt. Die Proben wurden auf einem Gitternetz (200 mesh) gesammelt und mit 2\% Uranyl Azetat und Bleizitrat kontrastiert.

\subsection{Morphometrie}

Um die Anzahl der entwickelten Tubuli pro Flächeneinheit zu bestimmen, wurden Whole-mount Proben SBA-markiert. Um die Anzahl von erzeugte Tubuli zu ermitteln, wurde WCIF ImageJ (Bethesda, Maryland, USA) als Morphometrieprogramm verwendet (Abb. 2b). Die Distanz zwischen der Basallamina von benachbarten Tubuli wurde auf vergrößerten DIN A4 Bildern vermessen. Unabhängig von ihrer Länge wurde die direkte Entfernung zwischen SBA-markierten Tubuli innerhalb eines mikroskopischen Feldes von $500 \times 850 \mu \mathrm{m}$ gemessen.

\subsection{Anzahl der kultivierten Konstrukte}

Für die vorliegenden Untersuchungen wurden 48 Proben isoliert und in Kultur genommen. Alle Experimente wurden mindestens in dreifacher Ausfertigung durchgeführt. Auch die im Text gezeigten Daten sind Durchschnittswerte von mindestens drei unabhängigen Experimenten. Alle durchgeführten Experimente stimmen mit den Grundsätzen des Tierethik-Komitees, der Universität Regensburg, Regensburg, Deutschland, überein. 


\section{ERGEBNISSE}

\subsection{Die strukturelle Anordnung von generierten Tubuli}

In den durchgeführten Experimenten wurden renale Stamm/Progenitorzellen aus dem Kortex der neonatalen Kaninchenniere isoliert und zwischen Lagen von Polyestervliesen kultiviert. Über einen Zeitraum von 13 Tagen wurde das Gewebe in einer Perfusionskammer mit chemisch definierten IMDM, in Kombination mit Aldosteron gehalten (Fig. 1).

Um das Wachstumsmuster der generierten Tubuli zu untersuchen, wurde das künstliche Interstitium am Ende der Kultur geöffnet. Dazu werden die Vliese mit einer feinen Pinzette voneinander getrennte. Die Proben wurden dann mit Ethanol fixiert und mit SBA markiert, um die räumliche Verteilung der generierten Tubuli sichtbar zu machen. Bei der konfokalen Fluoreszenzmikroskopie erkennt man zahlreiche markierte Tubuli, die längs, quer und schräg ausgerichtet sind (Fig. 2a). Die gezeigten Tubuli weisen eine durchgehend entwickelte Basallamina, polarisierte Epithelzellen und ein sichtbares Lumen auf.

Um die Anzahl der erzeugten Tubuli zu ermitteln, wurden Proben mit einem Morphometrieprogramm ausgewertet. In dem dargestellten Fall erkennt man zum Beispiel 63 Tubuli (Fig. 2b). Überraschenderweise zeigen die Whole-mount-Markierungen, dass die generierten Tubuli keinen Kontakt zueinander aufweisen (Fig. 2c). Kleine, mittlere und weite Abstände können gemessen werden. Um nähere Informationen über den Raum zwischen den generierten Tubuli zu erhalten, wurden $450 \mathrm{Ab}$ stände ausgewertet (Fig. 2d). Die Auswertungen zeigen, dass Abstände kleiner als 2,5 $\mu \mathrm{m}$ nicht auftreten. Abstände zwischen 5 und $25 \mu \mathrm{m}$ traten in 307 Fällen, also 68\% der Fälle auf. Es ist ersichtlich, dass der häufigste Abstand $10 \mu \mathrm{m}$ beträgt ( $n=59$ ). Im Gegensatz dazu findet man Abstände von 26 und $65 \mu \mathrm{m}$ weniger häufig ( $\mathrm{n}=143$ ). Die Häufung in dem Bereich zwischen 5 und $25 \mu \mathrm{m}$ unterstreicht, dass der Spalt zwischen den erzeugten Tubuli nicht zufällig sondern organisiert und dicht gepackt erscheint. 

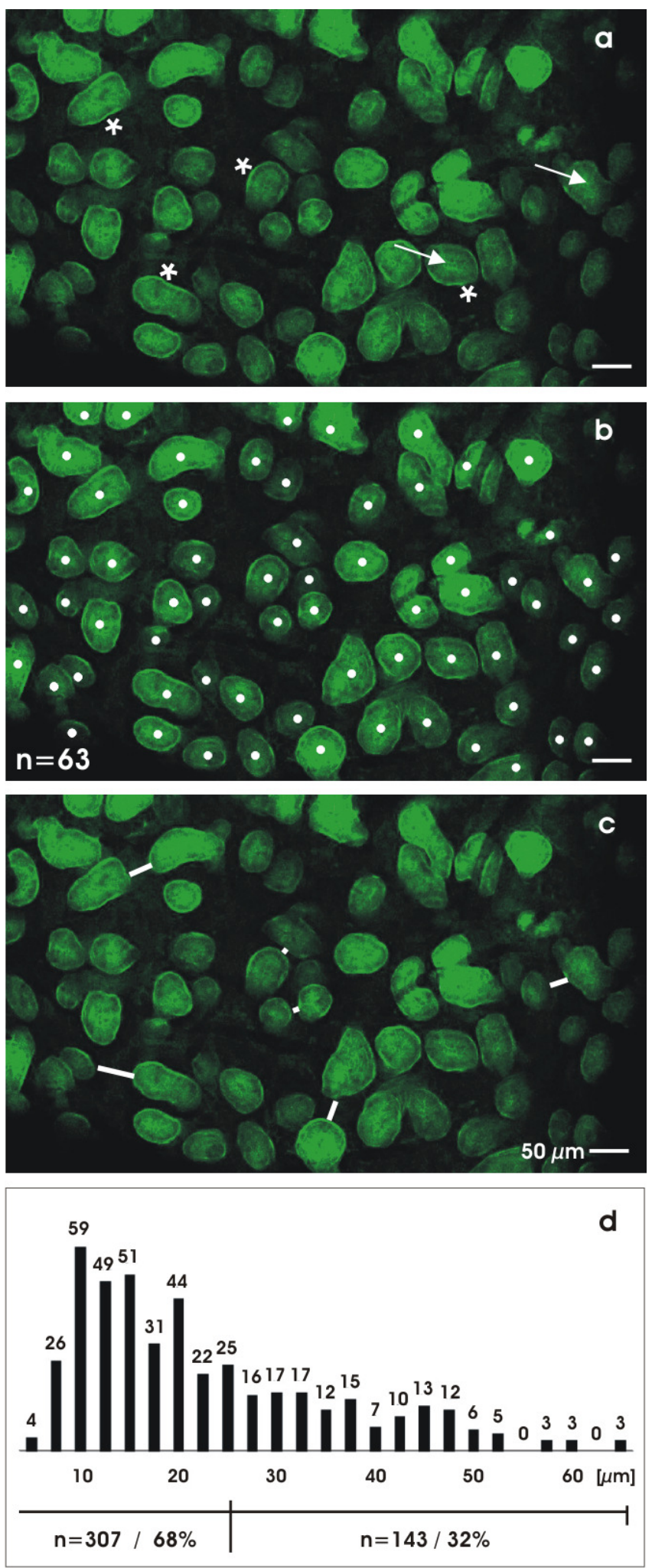

Fig.2a-d. Konfokale Fluoreszenzmikroskopie von SBA-markierter Tubuli, die über einen Zeitraum von 13 Tagen gewachsen sind. (a) Entwickelte Tubuli zeigen eine Basallamina (*) und ein Lumen (Pfeil). (b) Im gezeigten Präparat sind 63 entwickelte Tubuli zu erkennen. (c) Beispiele zeigen, dass die generierte Tubuli in einem kleinen, mittleren und großen Abstand wach- 
sen. (d) Die morphometrische Analysen über 450 Messungen zeigen, dass 68\% ( $n=307)$ der Tubuli über eine Distanz von 5 und $25 \mu \mathrm{m}$, während 32\% (n=143) über eine Distanz von 26 und $65 \mu \mathrm{m}$, getrennt sind.

\subsection{Extrazelluläre Matrix zwischen generierten Tubuli}

Um weitere Informationen über den interstitiellen Raum zwischen generierten Tubuli zu erhalten, wurden immunhistochemische Markierungen durchgeführt (Fig. 3). Kollagen Typ III wurden sowohl entlang der Basallamina als auch im Spalt zwischen den generierten Tubuli gefunden (Fig. 3a). Dieser Befund zeigt, dass an der basalen Seite der generierten Tubuli interstitielle Matrix in Form von Kollagen Typ III synthetisiert wird. Diese Experimente zeigen zusätzlich, dass Laminin $\gamma 1$ zusammen mit Kollagen Typ III in der Basallamina der generierten Tubuli lokalisiert ist, aber auch noch im Spaltraum zwischen zwei Tubuli erscheint (Fig. 3b). Man könnte daraus schlussfolgern, dass Kollagen Typ III und Laminin $\gamma 1$ die Bildung des Spaltraums zwischen den generierten Tubuli beeinflussen (Fig. 3c).
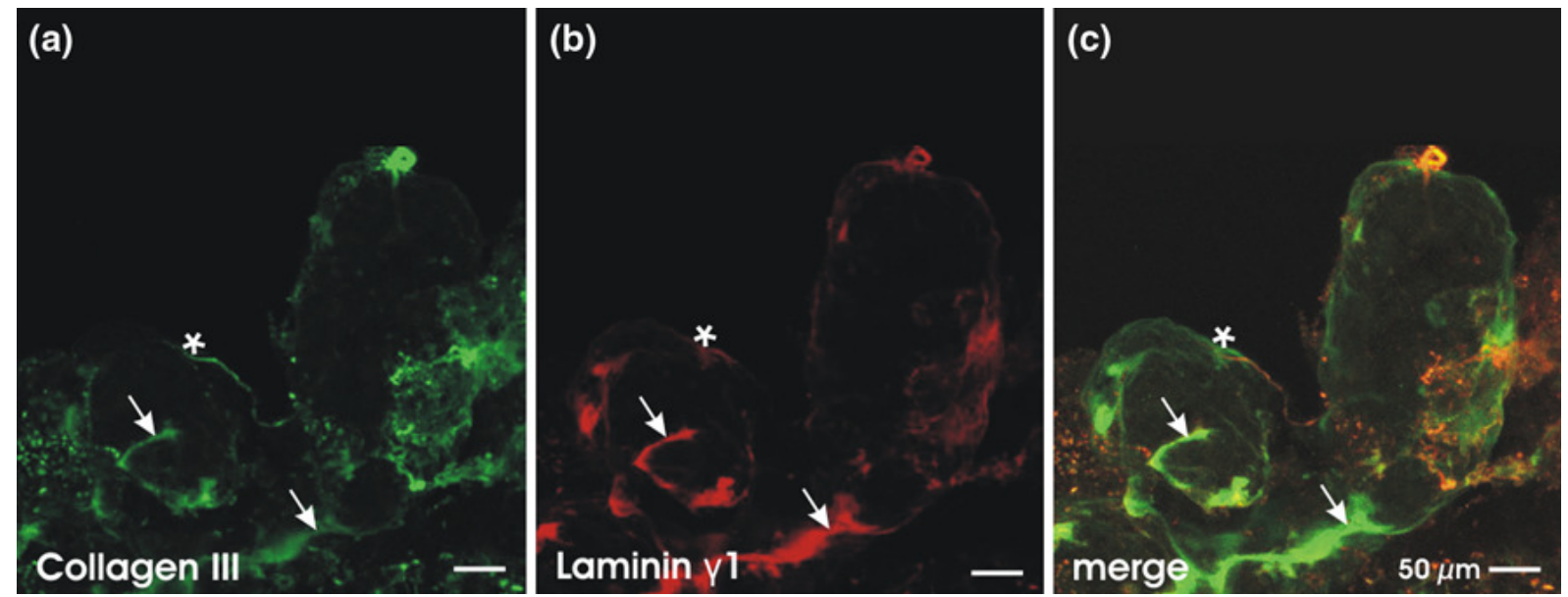

Fig. 3a-c. Konfokale Fluoreszenzmikrokopie anhand whole-mount-markierten Tubuli, die über einen Zeitraum von 13 Tagen an der Grenzfläche eines künstlichen Interstitiums generiert wurden. (a) Kollagen Typ III Markierung wird an der Basallamina $\left({ }^{*}\right)$ und innerhalb des intertubulären Spalts gefunden (Pfeil). (b) Markierung für Laminin $\gamma 1$ ist innerhalb der Basallamina $\left(^{*}\right)$ und innerhalb des intertubulären Spalts (Peil) zwischen den Tubuli zu erkennen. (c) Merge-Markierung zeigt auf, dass eine Kolokalisation beider Moleküle innerhalb der Basallamina $\left(^{*}\right)$ und innerhalb des intertubulären Spalts (Pfeil) vorhanden ist. 


\subsection{Strukturelle Eigenschaften des interstitiellen Raumes zwischen generierten Tubuli}

Um Einblicke in die Ultrastuktur des interstitiellen Raumes zwischen generierten Tubuli zu erhalten, wurde Transmissionselektronenmikroskopie durchgeführt (Fig. 4). Die Befunde zeigen, dass die generierten Tubuli ein differenziertes Epithel aufweisen (Fig. 4a). Die luminale Plasmamembran der epithelialen Zellen grenzt an ein klar sichtbares Lumen. Die luminalen und lateralen Plasmamembranen werden durch einen Komplex aus Tight-junktions verbunden. Die basale Plasmamembran steht in Kontakt mit der Basallamina. Eine stärkere Vergrößerung verdeutlicht, dass die Basallamina aus mehreren Schichten besteht, wie dies schon von der Niere bekannt ist (Fig. 4b). Die Lamina rara interna grenzt an die basale Plasmamembran der epithelialen Zellen, während die Lamina densa und die Lamina rara externa die Tubuli auf der äußeren Oberfläche bedecken. Die Lamina fibroreticularis fungiert als ein Verbindungselement zum interstitiellen Raum, welcher zahlreiche Kollagenfasern enthält. In manchen Fällen zeigen die Lamina rara externa und die Lamina fibroreticularis eine vergrößerte Dicke (Fig. 4c). Die variierende Schichtdicke könnte die unterschiedliche Distanz zwischen generierten Tubuli erklären, wie in Fig. $2 c$ und d gezeigt wird.
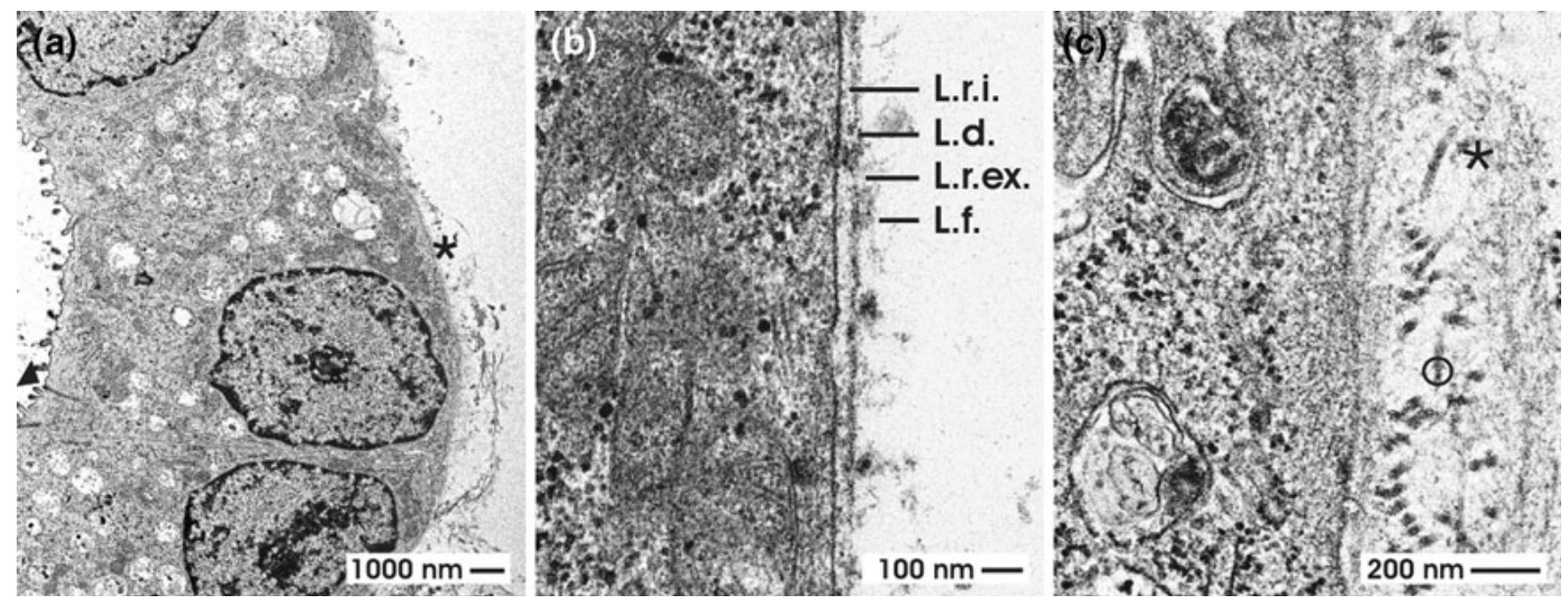

Fig. 4a-c. Transmissionselektronenmikrokopie an generierten Tubuli, die über einen Zeitraum von 13 Tagen kultiviert wurden. (a) Im Schnitt ist ein polarisiertes Epithel der Tubuli zu erkennen. An der Grenze zwischen Lumen und der lateralen Plasmamembran ist ein Komplex aus Tight-junktions ausgebildet (Pfeilspitze). Die basale Seite des Epithels liegt auf einer Basallamina $\left(^{*}\right)$. (b) Stärkere Vergrößerung zeigt den basalen Aspekte des Epithels und die Basallamina, welche aus der Lamina rara interna (I.r.i.), Lamina densa (I.d.), Lamina rara externa (I.r.ex.) und Lamina fibroreticularis (I.f.) besteht. 
(c) Höhere Vergrößerung ergibt, dass die Lamina fibroreticularis $\left({ }^{*}\right)$ gelegentlich eine größere Dicke besitzt, welche dann eine Vielzahl kollagener Fasern enthält (O).

Um weitere Informationen über Proteine der extrazellulären Matrix zu erhalten, die die räumliche Aufteilung der generierten Tubuli beeinflussen, wurde Rasterelektronenmikroskopie angewendet (Figs. 5a, 5d und 5g). Ein Blick auf die Oberfläche zeigt, dass die Tubuli Kontakt zum Polyestervlies halten. Diese Polyesterfasern haben einen durchschnittlichen Durchmesser von $10 \mu \mathrm{m}$ und weisen eine glatte Oberfläche ohne erkennbare Rauigkeit auf. Die erzeugten Tubuli haben sich in dem Raum zwischen den Polyesterfasern angesiedelt (Fig. 5a). Im Rasterelektronenmikroskop ist weiter zu erkennen, dass eine Basallamina die äußere Oberfläche der Tubuli bedeckt. Außerdem sieht man, dass ein Teil der Tubuli parallel zu einander wächst (Fig. 5d), während ein anderer Teil eine dichotome Ausbreitung aufweist (Fig. 5g). Man sieht ebenso einen Unterschied bezüglich der Annäherung zum Vlies. Einige Tubuli haben keinen Kontakt, während andere nur einen losen Kontakt zu den Polyesterfasern des Vlieses haben. Höhere Auflösungen zeigen, dass die Basallamina der generierten Tubuli von einem Netzwerk aus extrazellulären Matrixproteinen bedeckt ist, welches offensichtlich von den interstitiellen Zellen synthetisiert wurde (Figs. 5b, 5e und 5h). Zahlreiche kollagene Fasern erscheinen sowohl zwischen der Basallamina der generierten Tubuli, als auch neben benachbarten Fasern des Polyestervlieses. 

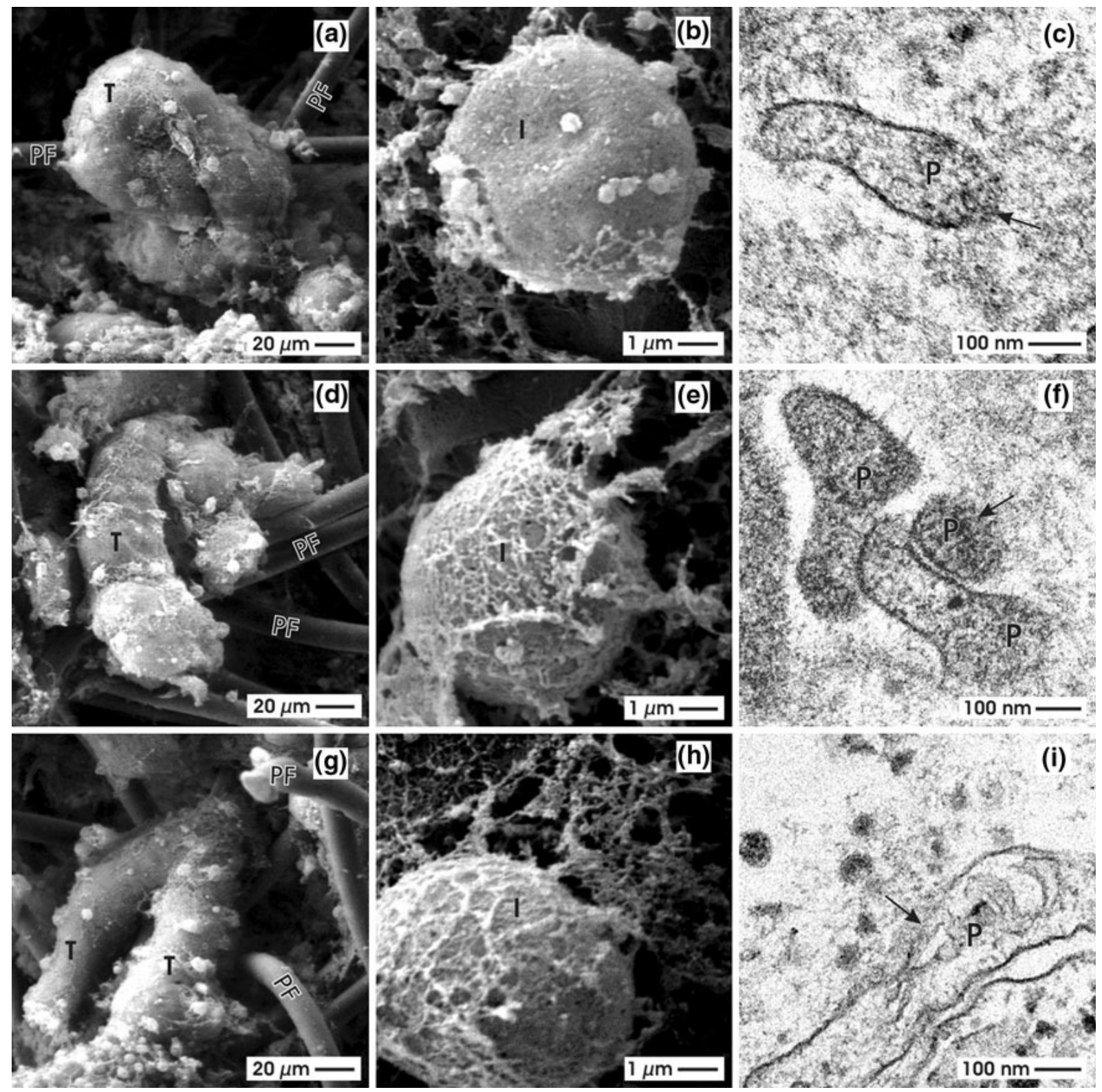

Fig. 5. Raster- (a, b, d, e, g, h) und Transmissionselektronenmikroskopie (c, f, i)zeigen generierte Tubuli nach 13 Tagen an der Grenzfläche eines künstlichen Polyesterinterstitiums. (a, d, g). Die Rasterelektronenmikroskopie zeigt, dass die Fasern des Polyestervlieses (PF) in längs, quer und schräg verlaufenden Bahnen liegen. Die Polyesterfasern haben eine glatte Oberfläche ohne erkennbare Erhebungen oder Rauigkeiten. Der Durchmesser der Polyesterfasern beträgt im Durchschnitt 10 $\mu \mathrm{m}$. Der Entwicklungsort der Tubuli $(T)$ liegt in dem Raum zwischen den Fasern. (a) Eine Basallamina bedeckt die äußere Oberfläche der Tubuli. (d, g) Ein Teil der Tubuli wächst in paralleler Ausrichtung, während ein anderer Teil ein dichotomes Wachstum zeigt. (b) Auf der äußeren Oberfläche der generierten Tubuli findet man verstreut interstitielle Zellen (I) in runder Form. (e, h) An der Oberfläche der interstitiellen Zellen findet sich ein Netzwerk aus Filopodien und extrazellulärer Matrix. (c, f, i) TEM zeigt, dass ein enger Kontakt zwischen Ausläufern (P) der interstitiellen Zellen und den angehefteten 
Fasern aus synthetisierter extrazellulärer Matrix besteht. An der Kontaktseite (Pfeil) erscheint die Plasmamembran aufgelöst. Amorphes Material ragt vom Zytoplasma durch die Plasmamembran zum extrazellulären Raum heraus.

Entlang der Basallamina von generierten Tubuli werden interstitielle Zellen gefunden (Fig. 5b, 5e und 5h). Diese besitzen nahezu runde Gestalt. In manchen Fällen erscheint ihre Oberfläche glatt (Fig. 5b), während andere ein Netzwerk von Filopodien oder extrazellulärer Matrix aufweisen (Figs. 5e und 5h). Die rasterelektronenmikroskopischen Aufnahmen der Filopodien von interstitiellen Zellen geben allerdings keine abschließende Information über das Ende der zellulären Anteile und den Anfangspunkt der extrazellulären Matrix (Figs. 5b, 5e und 5h). Aus diesem Grund wurde zusätzlich Transmissionselektronenmikroskopie durchgeführt, um den Übergang der zellularen Ausläufer zur extrazellulären Matrix genauer zu analysieren (Figs. 5c, 5f und 5i). Die Präparate zeigen, dass ein enger Kontakt zwischen den Ausläufern der interstitiellen Zellen und den Fasern der extrazellulären Matrix besteht. Überraschenderweise ist die Plasmamembran auf der Kontaktseite aufgelöst, sodass hier eine klare Mikrostruktur kaum zu erkennen ist. In jedem Fall ragt amorphes Material vom Zytoplasma durch die Plasmamembran zum extrazellulären Raum heraus.

\subsection{Interstitium des embryonalen renalen Parenchyms}

Die gezeigten Eigenschaften des Interstitiums, die bei generierten Tubuli gefunden wurden, könnten durch die Kulturexperimente beeinflusst sein (Fig. 3-5). Zum Vergleich wurde deshalb das Interstitium des embryonalen Parenchyms des äußeren Kortex einer neonatalen Nieren untersucht (Figs. 6-9). Anhand von Gefrierschnitten durch die embryonale Zone neonataler Kaninchennieren erkennt man in vertikaler (Fig. 6a und 6b) und horizontaler Sicht (Fig. 6c) Tubuli, die in ein Interstitium eingebettet sind. Bereits zu diesem Zeitpunkt der Entwicklung beobachtet man, dass Tubuli nicht in einem engen Kontakt zueinander stehen, sondern durch ein erstaunlich weites Interstitium getrennt sind. 

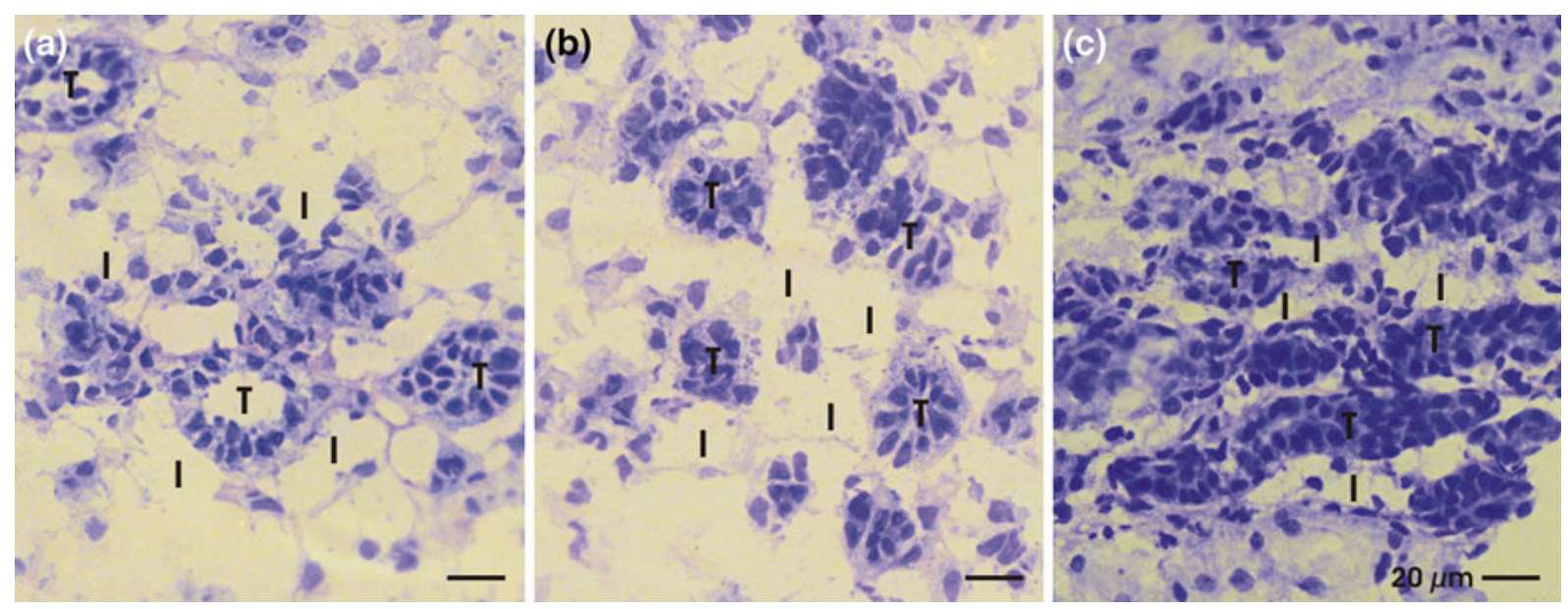

Fig. 6. Lichtmikroskopie von embryonalem renalem Parenchym innerhalb des äußeren Kortex der neonatalen Kaninchenniere. $(a, b)$ In vertikaler und (c) horizontaler Sicht sind Tubuli $(T)$ in einem weit erscheinenden Interstitium (I) eingebettet.

Um weitere Details des Interstitiums der sich entwickelnden neonatalen Nieren zu erhalten, wurden histochemische und ultrastrukturelle Analysemethoden angewendet. Demzufolge können in der embryonalen Rinde vier verschiedene Zonen unterschieden werden (Fig. 7a). Zwischen der Organkapsel und der Sammelrohrampulle befinden sich mesenchymale Nierenstamm/Progenitorzellen (mes), während innerhalb der Sammelrohrampullenspitze (A) epitheliale Stamm/Progenitorzellen lokalisiert sind. Seitlich des Ampullenhalses erkennt man als erstes sichtbares Zeichen der Nephronbildung Comma-shaped Bodies. Folgt man dem Ampullenhals erkennt man schließlich benachbart zum Ampullenschaft bereits entwickelte Nephrone. Zu erkenne ist ein Entwicklungsgradient, der sich vertikal von der Organkapsel über die Kortex corticis, die Spitze, den Hals und den Schaft der Sammelrohrampulle erstreckt. Im Folgenden wurde das Interstitium entlang dieses Entwicklungsgradienten untersucht.

Ein orientierter semidünner Schnitt zeigt, dass die mesenchymalen nephrogenen Stamm/Progenitorzellen unterhalb der Organkapsel von den epithelialen Stamm/Progenitorzellen in der Spitze der Sammelrohrampulle durch einen weiten interstitiellen Raum von einander getrennt werden (Pfeile)(Fig. 7b). Dieser Raum erstreckt sich von der Spitze über den Hals bis zum Schaft der 
(IC) sichtbar.
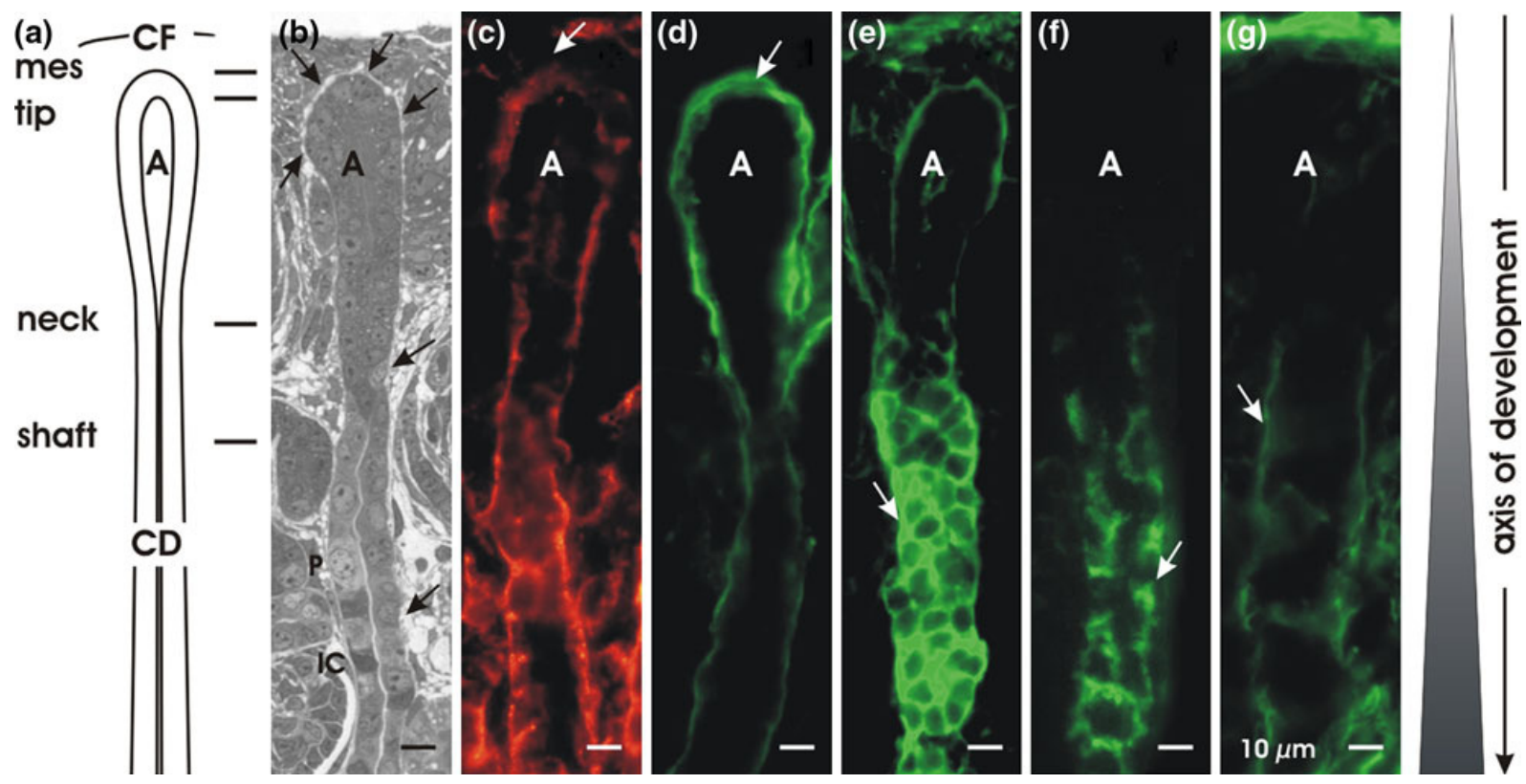

Fig. 7. Eigenschaften des Interstitiums in der neonatalen Kaninchenniere (a-g). (a) Unterhalb der Capsula fibrosa (CF) sind das Mesenchym (mes), die Spitze, der Hals und der Schaft der Ampulle (A) des Sammelrohres (CD) zu sehen. (b) Ein semidünner Schnitt zeigt, dass die mesenchymalen Stamm/Progenitorzellen der Sammelrohrampulle durch ein deutliches Interstitium (Pfeile) getrennt sind. Dieser Raum setzt sich seitlich der Spitze, über dem Hals und bis zum Hals der Sammelrohrampulle weiter. Im Bereich des Schaftes sind Principalzellen ( $P$, hell) und intercalated (IC, schwarz) Zellen zu erkennen. (c) Die immunhistochemische Markierung auf Laminin $\gamma 1$ fehlt im Bereich mesenchymaler Stamm/Progenitorzellen unterhalb der Kapsel (Pfeil), während eine durchgehende Markierung in der Basallamina der Sammelrohrampulle gefunden wird. (d) Eine ausgeprägte Markierung für $\mathrm{P}_{\mathrm{CD}}$ Amp1 sieht man auf der Basallamina der Ampullenspitze (Pfeil), während die Reaktion zum Hals und dem Schaft abnimmt. (e) Eine umgekehrte Reaktion wird für die SBA Markierung gefunden. Nur eine schwache Reaktion ist an der Basallamina der Ampullenspitze zu erkennen, während am Hals und dem Schaftbereich der Sammelrohrampulle eine starke zelluläre Markierung zu sehen ist (Pfeil). (f) Markierung für Na/K ATPase alpha 5 fehlt innerhalb der Spitze der Sammelrohrampulle, während eine intensive Reaktion im Hals und dem Schaft gefunden wird (Pfeil). (g) Kollagen Typ III fehlt im Bereich mesenchymaler Stamm/Progenitorzellen und rund um die Spitze der Sammelrohrampulle. Dafür ist eine deutliche Markierung im Bereich des Halses zu erkennen (Pfeil). 
Um genauerer Informationen über den Entwicklungsprozess zu erhalten, wurden histochemische Untersuchungen durchgeführt (Fig. 7c-g). Es fehlt die Markierung für Laminin $\gamma 1$ im Bereich mesenchymaler Stamm/Progenitorzellen unterhalb der Organkapsel (Pfeil). Dafür wird eine deutliche Reaktion in allen Zonen der Sammelrohrampulle gefunden (Fig. 7c). Eine intensive Reaktion für $P_{c d} A m p 1$ wird an der Basallamina der Ampullenspitze beobachtet, während die Intensität zum Hals und dem Schaft der Ampulle abnimmt (Fig. 7e). Vice versa verläuft die SBA-Markierung (Fig. 7e). Eine schwache Reaktion wird an der Basallamina der Ampullenspitze entdeckt, während innerhalb des Halses und des Schaftes einer Sammelrohrampulle eine starke zelluläre Markierung nachgewiesen wird. Innerhalb der Sammelrohrampulle fehlt eine Markierung für Na/K ATPase alpha 5 (Fig. 7f). Im Gegensatz dazu erkennt man eine intensive Reaktion für $\mathrm{Na} / \mathrm{K}$ ATPase alpha 5 im Hals (Pfeil) und im Schaft der Sammelrohrampulle. Überraschenderweise fehlt Kollagen Typ III im Bereich mesenchymaler Stamm/Progenitorzellen und an der Spitze der Sammelrohrampulle, während eine intensive Markierung am Hals (Pfeil) und am Schaft der Ampulle gefunden wird (Fig. 7g). Daraus kann geschlossen werden, dass Kollagen Typ III nicht das primäre Strukturelement des sich entwickelnden renalen Interstitiums sein kann.

\subsection{Morphologisch erkennbare Strukturelemente innerhalb des Interstitiums}

Um Einblicke in die strukturellen Eigenschaften des sich entwickelnden Interstitiums zu erhalten, wurden rasterelektronenmikroskopische Aufnahmen (SEM) durchgeführt (Fig. 8). Dabei erkennt man unter der Organkapsel mesenchymale nephrogene Stamm/Progenitorzellen. Diese weisen erstaunlich weite Abstände zu einander auf (Fig. 8a). Die Oberfläche dieser mesenchymalen Zellen zeigen kurze Mikrovilli neben zahlreichen Ausläufern, die in Kontakt zu Nachbarzellen stehen (Fig. 8b). Anhand der Aufnahmen ist nicht genau nachweisbar, ob die Zellausläufer, ausschließlich aus zellulärem Material, oder auch aus extrazellulärer Matrix bestehen. Im Gegensatz dazu weist die Spitze der 
Sammelrohrampulle eine raue Oberfläche auf, die aus verzweigten Fasern extrazellulärer Matrix besteht (Fig. 8c und 8d). Am Hals der Sammelrohrampulle nimmt sowohl die Anzahl als auch die Größe der Fasern ab, so dass eine glatte Oberfläche sichtbar wird (Fig. 8e und 8f). Hier sind nun zahlreiche runde Partikel erkennbar, die an den Fasern der extrazellulären Matrix anheften (Fig. 8f). Die Anzahl dieser runden Partikel nimmt in Richtung zum Schafft der Sammelrohrampulle ab. Starke Fasern aus extrazellulärer Matrix sind hier kaum sichtbar (Fig. 8g und 8h). Die rasterelektronischen Befunde belegen, dass die Strukturelemente des Interstitiums zwischen der Ampullenspitze, dem Hals und dem Schaft ganz unterschiedlich zusammengesetzt sind. Diese Segmentierung erscheint parallel zu histochemischen Veränderungen zu verlaufen, die entlang der Achse zwischen den mesenchymalen Stamm/Progenitorzellen, der Ampullenspitze, des Halses und dem Schaft der Sammelrohrampulle auftreten (Fig. 7) 

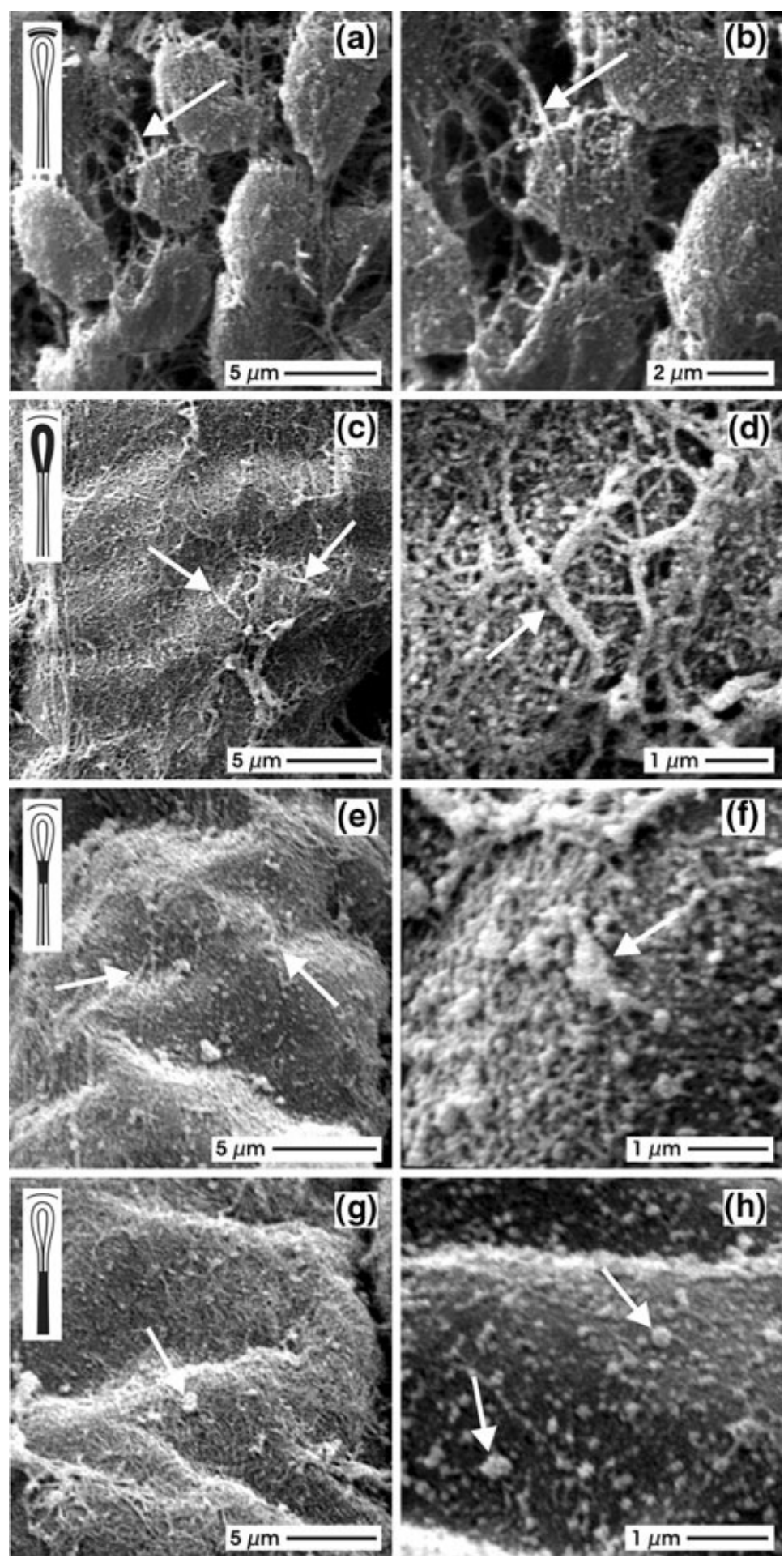

Fig. 8. Rasterelektronenmikroskopie (SEM) von der Rinde neonataler Kaninchennieren zeigt Strukturelemente des Interstitiums im Mesenchym unterhalb der Kapsel $(a, b)$, rund um die Spitze (c, d), dem Hals (e, f) und den Schaft (g, h) der Sammelrohrampulle. (a, b)Die Oberfläche der mesenchymalen Zellen weist kurze Mikrovilli und zahlreiche Filopodien auf (Pfeil), die Kontakte zu Nachbarzellen suchen. Es kann nicht geklärt werden, ob die Ausläufer ausschließlich aus zellulärem Material oder auch aus extrazellulärer Matrix bestehen. (c, d) Aufnahmen der Spitze der Sammelrohrampulle zeigen eine raue Oberfläche einschließlich verzweigter Fasern (Pfeil) bestehend aus extrazellulärer Matrix. (e, f) Entlang des Halses der Sammel- 
rohrampulle nimmt die Zahl und Größe der Fasern ab (Pfeil), so dass die Oberfläche glatter erscheint. Jetzt werden zahlreiche runde Partikel erkannt, die an Fasern angeheftet sind. $(g, h)$ Entlang des Schaftes der Sammelrohrampulle nimmt die Zahl der runden Partikel (Pfeile) innerhalb der Lamina fibroreticularis ab. Stärkere Fasern an extrazellulärer Matrix fehlen.

\subsection{Zellen im embryonalen Interstitium}

Zur Klärung der Frage, ob Zellen mit Strukturelementen im embryonalem Interstitium in Verbindung stehen, wurde Rasterelektronenmikroskopie entlang der Achse vom der Kortex corticis (Fig. 9a), der Ampullenspitze (Fig. 9c), dem Hals (Fig. 9e) und dem Schaft der Sammelrohrampulle (Fig. 9g) durchgeführt. Anhand dieser Aufnahmen sieht man Stamm/Progenitorzellen unterhalb der Organkapsel, also in der Zone des nephrogenen Mesenchyms, und dass zahlreiche Zellen in ein loses Netzwerk aus dünnen Fasern eingebettet sind (Pfeil, Fig. 9a). Dabei ist nicht erkennbar, ob ausschließlich Filopodien oder extrazelluläre Matrix vorliegt. Weiter unterhalb, also um die Spitze der Sammelrohrampulle herum, sind flache interstitielle Zellen mit zahlreichen Filopodien lokalisiert (Fig. 9c). Diese sind in ein dichtes Netzwerk aus Fasern extrazellulärer Matrix eingebettet. Am Hals der Ampulle sind die interstitiellen Zellen flach und zeigen zwei oder drei fußähnliche Ausläufer (Fig. 9e). Die Oberfläche der Zellen ist glatt. An der Kontaktseite mit extrazellulärer Matrix sind zahlreiche Ausläufer zu finden. Im Gegensatz dazu sind am Schaft der Ampulle interstitielle Zellen in einer kuboiden Form zu finden (Fig. 9g). An ihrer Zellseite, die der extrazellulären Matrix gegenübersteht, finden sich bemerkenswert fußähnliche Ausläufer (Pfeil). 

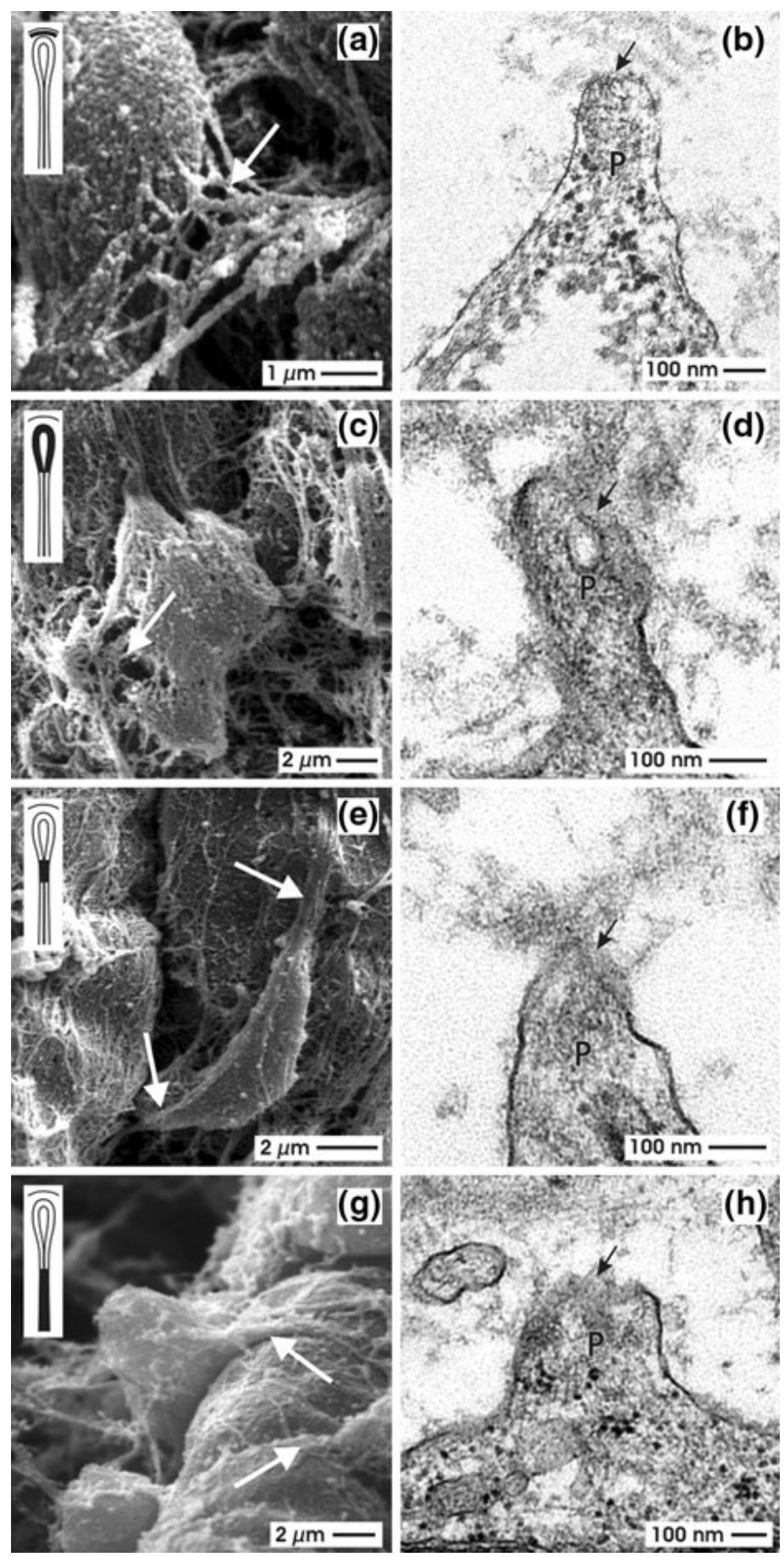

Fig. 9. Rasterelektronenmikroskopie (SEM) (a, c, e, g) und Transmissionselektronenmikroskopie (TEM) (b, d, f, h) der embryonalen Zone in neonatalen Kaninchenniere. (a) SEM zeigt, dass die Zellen im Bereich mesenchymaler Stamm/Progenitorzellen über ein loses Netzwerk aus dünnen Fasern (Pfeil) miteinander verbunden sind. (c) Um die Spitze der Sammelrohrampulle herum kann man flache interstitielle Zellen mit zahlreichen Filopodien und einem dichten Netz von Faser aus extrazellulärer Matrix erkennen (Pfeil). (e) Am Hals der Ampulle zeigen die interstitiellen Zellen zwei oder drei fußähnliche Ausläufer (Pfeile). An der Kontaktseite zur extrazellulären Matrix bilden sie zahlreiche Filopodien (g) Entlang des Schaftes der Sammelrohrampulle erscheinen die interstitiellen Zellen in fast kuboider Form. An der Zellseite, die zur 
extrazellulären Matrix gerichtet ist, halten fußähnliche Ausläufer und Filopodien Kontakt (Pfeil). (b, d, f, h) TEM zeigt einen engen Kontakt zwischen den Ausläufern (P) der interstitiellen Zellen und der extrazellulären Matrix. An der jeweiligen Kontaktstelle erscheint die Plasmamembran aufgelöst. Amorphes Material ragt durch die Plasmamembran ins Zytoplasma (Pfeil).

Anhand der rasterelektronenmikroskopischen Aufnahmen können dreidimensionale Strukturelemente des embryonalen Interstitiums untersucht werden (Figs. 9a, 9c, 9e und 9g). Folgt man den Filopodien der interstitiellen Zellen, so ist es unmöglich eine klare Demarkationslinie zwischen dem Ende einer Zelle und dem Beginn der extrazellulären Matrix zu erkennen. Um diesen speziellen Kontakt zu untersuchen, wurden transmissionselektronenmikroskopische Aufnahmen an den Stamm/Progenitorzellen im Cortex corticis der neonatalen Kaninchenniere (Fig. 9b), um die Ampullenspitze herum (Fig. 9d), dem Ampullenhals (Fig. 9f) und dem Schaft der Sammelrohrampulle (Fig. 9h) durchgeführt. Überraschenderweise zeigen die Aufnahmen ausnahmslos einen engen Kontakt zwischen den Zellausläufern und der extrazellulären Matrix. Jedoch ist diese Kontaktfläche besonders ausgebildet, weil die Plasmamembran an dieser Stelle aufgelöst zu sein erscheint. Gleiche Befunde wurden zwischen generierten Tubuli und dem Polyestervlies errungen (Fig. 5c, 5f und 5i). Zwischen dem Zytoplasma und dem interstitiellen Raum ist amorphes Material ausgebildet (Pfeil in Figs. 9b, 9d, 9f und 9h). 


\section{DISKUSSION}

Das Interstitium, das in allen parenchymalen Organen vorkommt, ist ein äußerst wichtiger funktioneller Raum. In der Niere erscheint das Interstitium als ein schmaler Spalt zwischen der Basallamina der Tubuli und den Blutgefäßen. Obwohl es unter dem Lichtmikroskop nur schwer erkennbar ist (Pfeil, Fig. 7b), spielt der interstitielle Raum eine entscheidende funktionelle Rolle in der gesunden Niere (Kaissling 2008). Es besteht aus extrazellulärer Matrix, der umgebenen Flüssigkeit und den interstitiellen Zellen. Der skeletonale Teil enthält hauptsächlich Kollagen Typ III, das die dreidimensionale Struktur des Organs stützt (Fleischmajer 1992). Alle Stoffe der Resorption und Sekretion der Tubuli können durch den flüssigkeitsgefüllten Raum fließen, der sich zwischen den einzelnen kollagenen Fasern befindet. In der erkrankten Niere infiltrieren inflammatorische Zellen diesen interstitiellen Raum. Der daraus resultierende Anstieg von interstitiellen Zellen und die damit verbundene Synthese von extrazellulärer Matrix verursachen Nierenfibrosen (Eddy 2005). Während diesem Prozess verlieren die Tubulizellen epitheliale Eigenschaften und konvertieren zu fibroblasten-ähnlichen Zellen (Burns 2007). Diese epithelial-mesenchymale Umwandlung (EMT) wird zum Beispiel von der Expression von Fibroblast-specific protein-1 (FSP1) (Iwano 2002), dem heat-shock Protein 47 (HSP 47) (Razzaque 2005, Hamilton 2006, Manwell 2007) und dem a-smooth muskel actin (aSMA) (Xu 2008) begleitet.

Die EMT von Zellen spielt auch eine zentrale Rolle, wenn Stamm/Progenitorzellen zur Unterstützung der Regeneration von akuten oder chronischen renalen Erkrankungen angewendet werden (Anglani 2008, Zeisberg 2008). Der Schlüssel zum Erfolg dieses therapeutischen Konzepts ist das Verstehen der zellbiologischen Prozesse, die die epitheliale Differenzierung während der Ausrichtung der Tubuli unterstützen und dabei die Umwandlung in mesenchymale Zellen verhindern. Der Prozess der Regeneration schließt auch diejenigen Mechanismen ein, die eine räumliche Aufteilung der benachbarten Tubuli organisieren. In der Niere wird diese Aufgabe durch extrazelluläre Matrixproteine erbracht, die während der Organentwicklung synthetisiert werden. Um erste Einblicke in die Entstehung dieser 
extrazellulären Matrix zu erhalten, wurden Tubuli mit Hilfe eines artifiziellen Polyesterinterstitiums generiert und morphologisch analysiert.

\subsection{Das Interstitium des sich entwickelnden renalen Parenchyms}

Genaue Einblicke in die Struktur des Interstitiums können mit exakt orientierten Schnitten durch die Rinde einer neonatalen Kaninchenniere erhalten werden (Figs. 7a und 7b). Hier können embryonales, reifendes und gereiftes Gewebe entlang einer Entwicklungsachse untersucht werden, die zwischen dem Cortex corticis, der Spitze der Sammelrohrampulle, dem Ampullenhals und dem Ampullenschaft zu finden sind (Kloth 1998). In der Rinde können vier unterschiedliche Zonen der Reifung unterschieden werden. Sie umfassen das Mesenchym (enthält nephrogene Stammprogenitorzellen), die Spitze (enthält epitheliale Stammprogenitorzellen), den Hals (Stadium der Reifung) und den Schaft (gereiftes Gewebe) einer Sammelrohrampulle (Fig. 7a).

Lichtmikroskopische Aufnahmen zeigen, dass sich das Interstitium des sich entwickelnden renalen Parenchyms sowohl zwischen den mesenchymalen Stamm/Progenitorzellen als auch um die basale Seite der Sammelrohrampullenspitze (Pfeil, Fig. 7b) ausdehnt. Der interstitielle Raum kann zudem als ein Spalt erkannt werden, der sich von der Ampullenspitze zum Hals und hinunter zum Schaft der Sammelrohrampulle entlang zieht. Von hier ab können gereifte P- und IC-Zellen innerhalb der Sammelrohrtubuli erkannt werden.

Die rasterelektronenmikroskopischen Befunde zeigen, dass der Bereich der mesenchymalen Stamm/Progenitorzellen erstaunlich weite Zellzwischenräume aufweist. Dieses ausgedehnte Interstitium (Fig. 8a und 8b) zeigt so gut wie keine extrazelluläre Matrix, dafür aber anastomosierende Verbindungen zwischen benachbarten Zellen. Allerdings kann mit den rasterelektronenmikroskopischen Aufnahmen nicht eindeutig geklärt werden, ob der Kontakt zwischen den Zellen nur durch Zellausläufer oder auch durch entstehende extrazelluläre Matrixproteine zustande kommt (Fig. 9a). Mehr In- 
formationen sind über transmissionselektronenmikroskopische Aufnahmen zu erhalten. Diese Befunde zeigen, dass extrazelluläre Matrixfasern in engem Kontakt zu fingerähnlichen zellulären Ausläufern stehen (Figs. 9b, 9d, 9f und 9h). Der Kontakt ist zu erkennen an amorphem extrazellulärem Material, welches durch die aufgelöste Plasmamembran aus dem Zytoplasma in den extrazellulären Raum hineinragt.

\subsection{Heterogenität der Strukturelemente in dem sich entwickelnden Interstitium}

Die Spitze der Sammelrohrampulle ist die spezifische Stelle, an der mesenchymale Stamm/Progenitorzellen mit epithelialen Stamm/Progenitorzellen reziprok interagieren (Schmidt-Ott 2005, Nigam 2009). Dieser molekulare Prozess resultiert in der Bildung von Comma-shaped Bodies als ein erstes morphologisches Zeichen der Nephronentwicklung. Dieser wichtige Austauschbereich im Interstitium an der Ampullenspitze wurde mit Hilfe von Rasterelektronenmikroskopie analysiert (Figs. 8c und 8d). Die Daten zeigen, dass ein dichtes Netzwerk extrazellulärer Matrix an dieser Stelle existiert. Allerdings werden an der Basalmembran der Sammelrohrampulle Fasern mit unterschiedlichen Durchmessern gefunden (Strehl 19999, Schumacher 2003). Am Ampullenhals nimmt die Rauigkeit, der Durchmesser und die Länge dieser skeletonalen Elemente ab (Figs. 8e und 8f). Anstelle dieser, werden mehr oder weniger runde und knochenförmige Partikel gefunden, die an die Fasern der extrazellulären Matrix angeheftet zu sein scheinen. Schließlich wird am Schaft der Sammelrohrampulle die Oberfläche der extrazellulären Matrix glatter und die Anzahl der Fasern vermindert sich (Figs. 8g und 8h). Daraus kann man schließen, dass die Art der Zusammensetzung des Interstitiums entlang den vier Zonen der Sammelrohrampulle ganz heterogen zusammengesetzt ist. Bis jetzt kann nicht beantwortet werden, welche molekulare Zusammensetzung die unterschiedlichen Segmente am äußeren Aspekt der Sammelrohrampulle ausmacht. Die Heterogenität der extrazellulären Matrix könnte mit besonderen Funktionen kongruent sein, die während der Nephrogenese auftreten. Je- 
doch sind genauere Informationen über individuelle strukturelle Zusammensetzungen bis zum heutigen Zeitpunkt nicht verfügbar und müssen in der Zukunft genauer untersucht werden.

\subsection{Entstehung von strukturellen Elementen im Interstitium}

Das hauptsächliche Strukturelement innerhalb des Interstitiums der Niere ist Kollagen Typ III, auch Retikulin, wie es früher bezeichnet wurde (Fleischmajer 1992, Razzaque 2005). Aus unseren Beobachtungen kann man schließen, dass die primäre Bildung von Kollagen Typ III eine treibende Kraft für die Ausformung skeletaler Elemente des Interstitiums ist und mit die Distanz zwischen generierenden Tubuli zu beeinflussen scheint. Interessanterweise zeigen immunhistochemische Markierungen, dass Kollagen Typ III sowohl im Bereich der mesenchymalen Stamm/Progenitorzellen als auch an der Spitze und im Hals der Sammelrohrampulle fehlt. Erst entlang des Ampullenschaftes wird Kollagen Typ III gefunden. Im Gegensatz dazu kommt Laminin $\gamma 1$ nicht nur am Schaft, sondern auch am Hals und an der Spitze der Sammelrohrampulle vor. Dafür kann es im Bereich der mesenchymalen Stamm/Progenitorzellen nicht nachgewiesen werden (Fig. 7c)(Minuth 2004). Folglich fehlt die Markierung von Kollagen Typ III in den Zonen der renalen Stammprogenitorzellen, wird aber dafür zusammen mit Laminin $\gamma 1$ in der Reifungszone entlang des Ampullenhalses und dem Ampullenschaft gefunden. Konsequenterweise muss man dafür ausgehen, dass Kollagen Typ III nicht das primäre skeletonale Element des Interstitiums im embryonalen renalen Parenchym der Sammelrohrampulle darstellt. Primäre Elemente sind statt dessen Kollagen Typ IV (Strehl 1999), SBA-markierte Moleküle innerhalb der Basallamina (Fig. 7e), Mikrofasern (Schumacher 2003) oder $\mathrm{P}_{\mathrm{cd}} \mathrm{Amp}_{1}$ (Strehl 2001) (Fig. 7d) als zutreffendere Kandidaten für ein Beispiel eines Strukturelementes. 


\subsection{Grenzfläche zwischen generierten Tubuli}

Last but not least, wurden auch Experimente durchgeführt, die die strukturellen Elemente des Interstitiums während der Generierung von Tubuli zum Inhalt haben (Figs. 2a-2c). In Whole-mount Präparaten ist nach SBA-Markierung zu erkennen, dass die generierten Tubuli nicht verschmelzen, sondern einen gewissen Abstand zu einander aufbauen. Die morphometrische Analysen zeigen, dass generierte Tubuli hauptsächlich eine Distanz zwischen 5 und $25 \mu \mathrm{m}$ aufweisen (Fig. 2d). Die genauen Ursachen für diese diskrete Distanz zwischen den generierten Tubuli sind bisher nicht bekannt. Darüber hinaus zeigen die generierten Tubuli auch eine Kolokalisation von Kollagen Typ III und Laminin $\gamma 1$ entlang der Basallamina (Fig. 3), wie dies auch in der Schaftzone der sich entwickelnden Teile der Niere zu sehen ist (Figs. 7c und 7g). Höchst beeindruckend ist die intensive Reaktion von Kollagen Typ III, die im Interstitium von generierten Tubuli gefunden wird. Dieses Ergebnis stellt heraus, dass Kollagen Typ III ein wichtiges Molekül ist, welches das künstliche Polyesterinterstitium mit der Basallamina der generierten Tubuli verbindet. Sowohl die Rasterelektronenmikroskopie als auch die Transmissionselektronenmikroskopie unterstützen diese Beobachtung. Es konnte gezeigt werden, dass die Basallamina von generierten Tubuli mit Bündeln synthetisierter extrazellulärer Matrix umgeben ist (Figs. 4 und 5a, 5d, 5g). Die morphometrischen Daten (Fig. 2d) weisen darauf hin, dass die Verbindung von Polyesterfasern des artifiziellen Interstitiums und synthetisierter extrazellulärer Matrix letztendlich die Distanz zwischen den generierten Tubuli bestimmen. Weitere Experimente sind in Arbeit, um Einblicke in diese Grenzfläche zu erhalten. 


\section{LITERATURVERZEICHNIS}

1 Anglani, F., et al. The renal stem cell system in kidney repair and regeneration. Front. Biosci. 13:6395-6405, 2008.

Ash, S. R., F. E. Cuppage, M. E. Hoses, and E. E. Selkurt. Culture of isolated renal tubules: a method of assessing viability of normal and damaged cells. Kidney Int. 1:55-60, 1975.

Burns, W. C., P. Kantharidis, and M. C. Thomas. The role of tubular epithelial-mesenchymal transition in progressive kidney disease. Cells Tissues Organs 1-3:222-231, 2007.

Bussolati, B., and G. Camussi. Stem cells and repair of kidney damage. G Ital Nefrol. 2:161$168,2008$.

Chhabra, P., and K. L. Brayman. The use of stem cells in kidney disease. Curr. Opin. Org. Transplant. 1:72-78, 2009.

Eddy, A. A. Progression in chronic kidney disease. Adv. Chronic Kidney Dis. 4:353-365, 2005.

Fleischmajer, R., et al. Immunochemical analysis of human kidney reticulin. Am. J. Pathol. 5:1225-1235, 1992.

Giuliani, S., et al. Ex vivo whole embryonic kidney culture: a novel method for research in development, regeneration and transplantation. J. Urol. 1:365-370, 2008.

9 Grobstein, C. Trans-filter induction of tubules in mouse metanephrogenic mesenchyme. Exp. Cell Res. 2:424-440, 1956.

Hamilton, A. M., and J. J. Heikkila. Examination of the stress-induced expression of the collagen binding heat shock protein, hsp47, in Xenopus laevis cultured cells and embryos. Comp. Biochem. Physiol. A Mol. Integr. Physiol. 1:133-141, 2006.

11 Heber, S., L. Denk, K. Hu, and W. W. Minuth. Modulating the development of renal tubules growing in serumfree culture medium at an artificial interstitium. Tissue Eng. 2:281-292, 2007.

12 Hopkins, C., J. Li, F. Rae, and M. H. Little. Stem cell options for kidney disease. J. Pathol. 2:265-281, 2009.

13 Iwano, M., et al. Evidence that fibroblasts derive from epithelium during tissue fibrosis. J. Clin. Invest. 3:341-350, 2002.

14 Kaissling, B., and M. Le Hir. The renal cortical interstitium: morphological and functional aspects. Histochem. Cell Biol. 2:247-262, 2008.

15 Kloth, S., et al. Transitional stages in the development of the rabbit renal collecting duct. Differentiation 1:21-32, 1998. 
Manwell, L. A., and J. J. Heikkila. Examination of KNK437- and quercetin-mediated inhibition of heat shockinduced heat shock protein gene expression in Xenopus laevis cultured cells. Comp. Biochem. Physiol. A Mol. Integr. Physiol. 3:521-530, 2007.

Minuth, W. W., A. Blattmann, L. Denk, and H. Castrop. Mineralocorticoid receptor, heat shock proteins and immunophilins participate in the transmission of the tubulogenic signal of aldosterone. J. Epithel. Biol. Pharmacol. 11:24-34, 2008.

Minuth, W. W., L. Denk, K. Hu, H. Castrop, and C. Gomez-Sanchez. The tubulogenic effect of aldosterone is attributed to intact binding and intracellular response of the mineralocorticoid receptor. Cent. Eur. J. Biol. CEJB 2(3):3307-3325, 2007.

Minuth, W. W., L. Sorokin, and K. Schumacher. Generation of renal tubules at the interface of an artificial interstitium. Cell. Physiol. Biochem 4-6:387-394, 2004.

Nigam, S. K., and M. M. Shah. How does the ureteric bud branch? J. Am. Soc. Nephrol. 20:1465-1469, 2009.

21 Razzaque, M. S., V. T. Le, and T. Taguchi. Heat shock protein 47 and renal fibrogenesis. Contrib. Nephrol. 148: 57-69, 2005.

22 Razzaque, M. S., et al. Synthesis of type III collagen and type IV collagen by tubular epithelial cells in diabetic nephropathy. Pathol. Res. Pract. 11:1099-1104, 1995.

23 Sariola, H. Nephron induction. Nephrol. Dial. Transplant. 17(9):88-90, 2002.

24 Saxe'n, L., and E. Lehtonen. Embryonic kidney in organ culture. Differentiation 1:2-11, 1987.

25 Schmidt-Ott, K. M., et al. Novel regulators of kidney development from the tips of the ureteric bud. J. Am. Soc. Nephrol. 7:1993-2002, 2005.

26 Schumacher, K., R. Strehl, and W. W. Minuth. Characterization of micro-fibers at the interface between the renal collecting duct ampulla and the cap condensate. Nephron. Exp. Nephrol. 2:e43-e54, 2003.

27 Strehl, R., S. Kloth, J. Aigner, P. Steiner, and W. W. Minuth. PCDAmp1, a new antigen at the interface of the embryonic collecting duct epithelium and the nephrogenic mesenchyme. Kidney Int. 6:1469-1477, 1997.

28 Strehl, R., and W. W. Minuth. Partial identification of the mab (CD)Amp1 antigen at the epithelial-mesenchymal interface in the developing kidney. Histochem. Cell Biol. 5:389-396, 2001.

29 Strehl, R., V. Trautner, S. Kloth, and W. W. Minuth. Existence of a dense reticular meshwork surrounding the nephron inducer in neonatal rabbit kidney. Cell Tissue Res. 3:539-548, 1999.

30 Sutterlin, G. G., and G. Laverty. Characterization of a primary cell culture model of the avian renal proximal tubule. Am. J. Physiol. 1 Pt 2:R220-R226, 1998. 
$31 \mathrm{Xu}, \mathrm{G}$. , and X. Liu. Aldosterone induces collagen synthesis via activation of extracellular signalregulated kinase 1 and 2 in renal proximal tubules. Nephrology (Carlton) 8:694- 701, 2008.

32 Yokoo, T., A. Fukui, K. Matsumoto, and M. Okabe. Stem cells and kidney organogenesis. Front. Biosci. 13:2814- 2832, 2008.

33 Zeisberg, E. M., S. E. Potenta, H. Sugimoto, M. Zeisberg, and R. Kalluri. Fibroblasts in kidney fibrosis emerge via endothelial-to-mesenchymal transition. J. Am. Soc. Nephrol. 12:2282$2287,2008$. 


\title{
Danksagung
}

Allen die zum Entstehen dieser Arbeit in direkter oder indirekter Weise beigetragen haben, möchte ich an dieser Stelle meinen aufrichtigen Dank aussprechen.

\author{
Herrn Prof. Dr. W. W. Minuth
}

danke ich für die freundliche Überlassung des Themas sowie für seine bereitwillige und verständnisvolle Unterstützung bei der Durchführung und Anfertigung meiner Arbeit recht herzlich. Seine jederzeit offene Tür und Diskussionsbereitschaft trug maßgeblich zum Erfolg dieser Arbeit bei.

Darüber hinaus möchte ich meinen Kolleginnen Frau Dr. Anne Glashauser und Frau Lucia Denk für das freundschaftliche Arbeitsklima und die vielfältige Unterstützung danken.

Meinen Eltern danke ich von ganzem Herzen, dass sie mir meine Ausbildung ermöglicht und mir stets zur Seite gestanden haben.

Mein Dank gilt auch denen, die nicht namentlich aufgeführt sind, aber erheblich zum Gelingen und Vollenden dieser Arbeit beigetragen haben. 


\section{$\underline{\text { Lebenslauf }}$}

Name: Christian Miess

Anschrift: Hochweg 75; 93049 Regensburg

Geboren am: 02.02.1985 in Erlangen

Staatsangehörigkeit: Deutsch

Familienstand: Ledig

Schulen: 1990 Vorschule Königstein

1991 Killermann - Grundschule Regensburg

1995 Goethe-Gymnasium Regensburg

Studium: $\quad$ 01.10.2004 - 31.09.2010 Studium der Zahnheilkunde an der Universität

Regensburg

Examina: 06/2004 Abitur am Goethe-Gymnasium Regensburg

10/2005 Naturwissenschaftliche Vorprüfung

10/2007 Zahnärztliche Vorprüfung der Zahnheilkunde

2010 Staatsexamen Zahnmedizin 
